\title{
Use of cellulose acetate-tin (IV) phosphate composite (CA/TPC) in highly effective removal and recovery of heavy metal ions
}

\author{
Suriti Sharma • Navin Chandra Kothiyal • \\ Bhim Singh Rathore $\cdot$ Sumit Sharma
}

Received: 9 October 2014/ Accepted: 11 January 2015/Published online: 19 February 2015

(c) The Author(s) 2015. This article is published with open access at Springerlink.com

\begin{abstract}
A novel cellulose acetate-tin (IV) phosphate composite material has been synthesized under varying conditions. The material was characterized by FTIR, SEM, EDX and XRD. The composite material was explored for its use in separation of toxic metal cations present in electroplating waste discharge and similar synthetic fluid by varying the system conditions [temperature $(298-313 \mathrm{~K})$, pH (2-12), time (10-420 min), dosage $(1-10 \mathrm{~g})$ and initial concentration of metal cations $\left.\left(1.0-15.0 \mathrm{mg} / \mathrm{dm}^{3}\right)\right]$. Highest removal rate was achieved for $\mathrm{Cr}^{3+}, \mathrm{Ni}^{2+}$ and $\mathrm{Zn}^{2+}$ (99, 98 and $94 \%$ ) under optimal conditions. Experimental equilibrium data for $\mathrm{Cr}^{3+}, \mathrm{Ni}^{2+}$ and $\mathrm{Zn}^{2+}$ ions fitted well with Langmuir isotherms $\left(R^{2}>0.99\right)$. The adsorption capacities for $\mathrm{Cr}^{3+}, \mathrm{Ni}^{2+}$ and $\mathrm{Zn}^{2+}$ ions were found to be $31.5,43.7$ and $43.4 \mathrm{mg} / \mathrm{g}$. Pseudo-second-order model explained the kinetics of adsorption $\left(R^{2}>0.99\right)$ for all the metal ions undertaken in the study. Thermodynamic parameters such as $\Delta G, \Delta S$ and $\Delta H$ show spontaneity and endothermic nature of the process at all the concentration ranges studied $\left(2-15 \mathrm{mg} / \mathrm{dm}^{3}\right)$. Desorption of metal ion from (CA/TPC) surface was carried out using $0.1 \mathrm{~N}$
\end{abstract}

Electronic supplementary material The online version of this article (doi:10.1007/s40090-015-0031-2) contains supplementary material, which is available to authorized users.

Suriti Sharma · N. C. Kothiyal $(\bowtie) \cdot$ Sumit Sharma Department of Chemistry, Dr. B.R. Ambedkar National Institute of Technology, Jalandhar 144011, Punjab, India

e-mail: kothiyalnc@nitj.ac.in

Sumit Sharma

e-mail: sumit24nitj@gmail.com

B. S. Rathore

Department of Chemistry, Shoolini University,

Solan 173212, Himachal Pradesh, India nitric acid as an eluent under varying system pHs (1-6). Maximum desorption's for all the metal ions were observed at $\mathrm{pH}$ 1. The adsorption efficiencies of CA/TPC for the metal ions were maintained after four consecutive cycles of adsorption/desorption process. The loss in the dry weight of CA/TPC was not more than $10 \%$ after each cycle of process. Due to easy and high regeneration properties of CA/TPC, it was found to be economical and have shown potential benefits in recovery of metal ions from wastewater.

Keywords CA/TPC Electroplating wastewater .

Isotherm $\cdot$ Kinetic model $\cdot$ Desorption

$\begin{array}{ll}\text { Abbreviations } \\ \text { CA/ } & \text { Cellulose acetate-tin (IV) phosphate composite } \\ \text { TPC } & \\ n & \text { Adsorption intensity }\left(\mathrm{g} / \mathrm{dm}^{3}\right) \\ b & \text { Affinity of the binding sites }\left(\mathrm{dm}^{3} / \mathrm{mg}\right) \\ A & \text { Temkin constant }(\mathrm{mg} / \mathrm{g}) \\ B & \text { Temkin constant }\left(\mathrm{dm}^{3} / \mathrm{mg}\right) \\ q_{t} & \text { Adsorption capacity at time }(t)(\mathrm{mg} / \mathrm{g}) \\ q_{\mathrm{e}} & \text { Adsorption capacity at equilibrium }(\mathrm{mg} / \mathrm{g}) \\ h & \text { Initial adsorption rate as } t \rightarrow 0(\mathrm{mg} / \mathrm{g} \mathrm{min}) \\ k_{2} & \text { Pseudo-second-order constant }(\mathrm{g} / \mathrm{mg} \mathrm{min}) \\ \alpha & \text { Initial metal adsorption rate }(\mathrm{mg} / \mathrm{g} \mathrm{min}) \\ \beta & \text { Desorption constant }(\mathrm{g} / \mathrm{mg}) \\ C & \text { Intercept } \\ K_{\mathrm{id}} & \text { Initial rate of intraparticle diffusion } \\ & \left.\text { (mg/dm }{ }^{3} \text { min }{ }^{1 / 2}\right) \\ \Delta G & \text { Gibbs free energy }(\mathrm{kJ} / \mathrm{mol}) \\ \Delta H & \text { Enthalpy change }(\mathrm{kJ} / \mathrm{mol}) \\ \Delta S & \text { Entropy change }(\mathrm{J} / \mathrm{K} \mathrm{mol}) \\ k_{\mathrm{c}} & \text { Equilibrium constant of the adsorption process } \\ T & \text { Absolute temperature }(\mathrm{K})\end{array}$


$R \quad$ Universal gas constant $(8.314 \mathrm{~J} / \mathrm{K} \mathrm{mol})$

$t \quad$ Adsorption time (min)

$R_{\mathrm{L}} \quad$ Dimensionless separation factor

$C_{0} \quad$ Initial liquid phase concentrations of metal ions $\left(\mathrm{mg} / \mathrm{dm}^{3}\right)$

$C_{\mathrm{e}} \quad$ Equilibrium liquid phase concentrations of metal ions $\left(\mathrm{mg} / \mathrm{dm}^{3}\right)$

$C_{\mathrm{AD}} \quad$ Equilibrium concentration of metal on the adsorbent $\left(\mathrm{mg} / \mathrm{dm}^{3}\right)$

$q_{\mathrm{e}, \mathrm{Cal}} \quad$ Calculated equilibrium adsorption capacity (mg/g)

$q_{\mathrm{e}, \text { exp. }} \quad$ Experimental equilibrium adsorption capacity (mg/g)

$\chi^{2} \quad$ Chi-square

$q_{\mathrm{m}, \mathrm{Cal}}$. Calculated maximum adsorption capacity $(\mathrm{mg} / \mathrm{g})$

$q_{\mathrm{m} \text {,exp. }} \quad$ Experimental maximum adsorption capacity (mg/g)

$R^{2} \quad$ Correlation coefficient

AAS Atomic absorption spectrophotometer

$k_{\mathrm{f}} \quad$ Multilayer adsorption capacity $(\mathrm{mg} / \mathrm{g})$

$V \quad$ Volume of metal solution $\left(\mathrm{dm}^{3}\right)$

AD Adsorbent dosages

$m \quad$ Mass of adsorbent (g)

EPU Electroplating unit

\section{Background}

Inadequate wastewater management has resulted continuous discharge of heavy metals in the aquatic system. The heavy metals released in excess have significant adverse environmental impacts. These are toxic to many organ systems including the heart, bone, intestine, kidney, reproductive and nervous system, in varying degrees. Consequently, significant research attention has recently been focused on the environmental behavior of heavy metals. The heavy metals are easily concentrated by the food chain, which threatens human health. The heavy metals have entered into the atmosphere, water and soil through mining, electroplating, dyeing, tanning and metal processing industries in large scale [1-4]. In drinking water, the authorized limit set by WHO for the three metals is chromium $\left(0.05 \mathrm{mg} / \mathrm{dm}^{3}\right)$, nickel $\left(0.07 \mathrm{mg} / \mathrm{dm}^{3}\right)$ and zinc $\left(3.0 \mathrm{mg} / \mathrm{dm}^{3}\right)$. Therefore, it is necessary to remove heavy metals from the wastewaters before they are discharged into the natural water system. Various materials, such as $\left(\mathrm{MnO}_{2} / \mathrm{CNT}\right)$ nanocomposite, fertilizer waste activated carbon, waste materials, $\mathrm{MWCNT} / \mathrm{TiO}_{2}$ composite, alumina-coated $\mathrm{CNT}$, orange peel/ $\mathrm{Fe}_{2} \mathrm{O}_{3}$ nanoparticle composite and agriculture waste, have been used to remove hazardous wastes from water [4-16]. Several other techniques have also been developed for the treatment of undesired waste containing heavy metals and dyes [3, 17, 18]. Among these, ion exchange technique is the most common and effective method for the treatment and identification of industrial wastes [19, 20]. The inorganic ion exchange materials are more stable to high temperatures and ionizing radiation than organic exchangers. For this purpose, first inorganic ion exchangers and later on organic resins have been used [21]. However, inorganic ion exchange materials have their own limitations, e.g., these materials in general are reported to be not much reproducible in behavior and fabrication of fine powder of it in rigid-type media suitable for column operations is quite difficult. Organic-inorganic hybrid composite materials, due to its exceptional chemical, mechanical and thermal properties as compared to pure inorganic and organic materials, have attracted a great attention in scientific community. Converting the organic and inorganic materials into an organic-inorganic hybrid composite with better properties is an economic method which has been a hot topic [22-38]. The organic-inorganic hybrid composite minimizes the limitations of organic and inorganic materials by modifying individual properties of each of the organic and inorganic materials. These materials have been obtained by incorporating the organic polymers into the matrix of inorganic precipitates of multivalent metal acid salts [39]. Recently, use of organic-inorganic hybrid composite to separate metal ions has been discussed widely [24, 37, 40]. Therefore, organic-inorganic hybrid composite, cellulose acetate-tin (IV) phosphate, has been preferred to synthesize and use in heavy metal decontamination. This material has better granulometric properties, good ion exchange capacity, reproducibility and possesses good selectivity for heavy metals [21]. However, to our knowledge, there is little or no information about the preparation of cellulose acetatetin (IV) phosphate composites (CA/TPC) and their use in separation and removal of heavy metals from electroplating wastewater. Thus, this study was aimed at developing a simple and efficient laboratory-scale adsorption technique to remove heavy metals such as chromium, nickel and zinc from synthetic and electroplating wastewater using cellulose acetate-tin (IV) phosphate composite (CA/TPC) material. The material was characterized using scanning electron microscopy (SEM), energy-dispersive X-ray spectroscopy (EDX), X-ray diffraction (XRD) and Fourier transform-infrared spectroscopy (FT-IR) techniques. The adsorption mechanism was evaluated from kinetics, isotherms and thermodynamics. 


\section{Materials and methods}

\section{Chemicals}

All solutions were prepared from analytical reagent grade chemicals procured from Merck Specialty Chemicals, (P) Ltd. Mumbai, India, and Millipore Milli-Q grade deionized water (conductivity of $14.7 \mathrm{M} \mathrm{cm}$ ).

\section{Glasswares}

All glasswares of Borosil make glass (A grade) were used in the study. Glasswares were dipped in $10 \%(\mathrm{v} / \mathrm{v}) \mathrm{HNO}_{3}$ overnight and subsequently rinsed twice with deionized water to remove any possible interference by other metals.

Synthesis of cellulose acetate-tin (IV) phosphate

The composite ion exchanger material was prepared by the sol-gel mixing of cellulose acetate into the inorganic precipitate of tin (IV) phosphate [32]. In this process, tin (IV) phosphates were prepared by adding $0.1 \mathrm{M}$ tin (IV) chloride and $0.1 \mathrm{M}$ sodium dihydrogen phosphate drop wise with continuous shaking in equal volume ratio (1:1). The $\mathrm{pH}$ variation was adjusted by adding $1 \mathrm{M}$ nitric acid or $1 \mathrm{M}$ ammonia solutions. The mixture was stirred constantly for $2 \mathrm{~h}$ at $303 \pm 2 \mathrm{~K}$ to obtain precipitate of tin (IV) phosphate. The gel of cellulose acetate was added drop wise into the inorganic precipitate of tin (IV) phosphate and mixed thoroughly with a constant stirring for $4 \mathrm{~h}$. The mixture was kept for $24 \mathrm{~h}$ in the mother liquor for digestion. The supernatant liquid was removed, and the precipitates were washed with double distilled water several times to remove excess reagents or impurities (if any). The product was dried at $313 \pm 2 \mathrm{~K}$ in an oven and then converted to $\mathrm{H}^{+}$form by placing them in $1 \mathrm{M} \mathrm{HNO}_{3}$ solution. The activated ion exchanger was washed with double distilled water to remove excess acid. The material was finally dried at $313 \pm 2 \mathrm{~K}$ in a hot air oven and preserved for use in desiccators. A number of samples were prepared using the procedure.

\section{Electroplating wastewater}

An over view of electroplating industries chosen for sampling, containing chromium, nickel and zinc plating rinse water, is shown in Table 1. Average physicochemical characteristics of electroplating rinse water are as follows: $\mathrm{pH}, 7.8$, conductivity, $1.54 \mathrm{mS} \mathrm{cm}^{-1}, \mathrm{COD}, 275.6 \mathrm{mg} /$ $\mathrm{dm}^{3}$, TDS, $112.2 \mathrm{mg} / \mathrm{dm}^{3}$. The concentrations of the heavy metals have been found in the four wastewater samples, Table 2. The average concentrations of chromium $\left(16.21 \mathrm{mg} / \mathrm{dm}^{3}\right)$, nickel $\left(15.41 \mathrm{mg} / \mathrm{dm}^{3}\right)$ and zinc $\left(13.23 \mathrm{mg} / \mathrm{dm}^{3}\right)$ were shown to exceed the prescribed legal limits. The COD content $\left(275.6 \mathrm{mg} / \mathrm{dm}^{3}\right)$ in the wastewater samples also exceeds the authorized limit.

\section{Batch adsorption studies}

Stock solutions $\left(1,000 \mathrm{mg} / \mathrm{dm}^{3}\right)$ of nickel, chromium and zinc were prepared by dissolving required quantity of

Table 1 Over view of electroplating industries chosen for sampling

\begin{tabular}{lllllllll}
\hline S. no. & Unit & $\begin{array}{l}\text { Name of } \\
\text { the industry }\end{array}$ & $\begin{array}{l}\text { Establishment } \\
\text { year }\end{array}$ & $\begin{array}{l}\text { Annual } \\
\text { turn over }\end{array}$ & Employees & $\begin{array}{l}\text { Sampling } \\
\text { date }\end{array}$ & $\begin{array}{l}\text { Sample } \\
\text { code }\end{array}$ & $\begin{array}{l}\text { Effluent discharged } \\
\text { (L/week) }\end{array}$ \\
\hline 1. & Cr plating & Victor Tools Ltd. & 1954 & 55 crores & $500-600$ & Sept. 2012 & EPU-3 & 16,800 \\
2. & Ni plating & Ajay Tools Limited & 1973 & 20 crores & $300-350$ & Sept. 2012 & EPU-1 & 11,000 \\
3. & Zn plating & Ajay Tools Limited & 1973 & 20 crores & $300-350$ & Sept. 2012 & EPU-1 & 11,000 \\
4. & Treated water & Victor Tools Ltd. & 1954 & 55 crores & $500-600$ & Sept. 2012 & EPU-3 & 16,800 \\
\hline
\end{tabular}

Table 2 Concentration of heavy metals observed in electroplating industrial effluents chosen for sampling $\left(\mathrm{mg} / \mathrm{dm}^{3}\right)$

\begin{tabular}{|c|c|c|c|c|c|c|}
\hline \multirow[t]{2}{*}{ S. no. } & \multirow[t]{2}{*}{ Metal } & \multicolumn{5}{|c|}{ Sampling code of the unit } \\
\hline & & EPU-1 & EPU-2 & EPU-3 & EPU-4 & WHO limit ${ }^{b}$ \\
\hline 1. & Chromium $^{\mathrm{a}}$ & 17.77 & 13.90 & 14.89 & 11.20 & 0.05 \\
\hline 2. & Nickel & 15.21 & 17.51 & 13.52 & 10.50 & 0.07 \\
\hline 3. & Zinc & 12.50 & 18.00 & 9.201 & 09.50 & 3.0 \\
\hline 4. & Iron & 13.40 & 0.312 & 0.431 & 1.235 & - \\
\hline
\end{tabular}

a Total chromium

${ }^{\mathrm{b}}$ Guideline values in drinking water 
$\mathrm{Ni}\left(\mathrm{SO}_{4}\right)_{2} \cdot 6 \mathrm{H}_{2} \mathrm{O}, \mathrm{Cr}_{2}\left(\mathrm{SO}_{4}\right)_{3} \cdot 12 \mathrm{H}_{2} \mathrm{O}$ and $\mathrm{ZnSO}_{4} \cdot 7 \mathrm{H}_{2} \mathrm{O}$ in $\left(1,000 \mathrm{~cm}^{3}\right)$ deionized water $(\mathrm{pH} \mathrm{7})$. The test solutions of nickel, chromium and zinc were prepared by serial dilution of stock solutions using graduated micropipette and stored at $277 \pm 2 \mathrm{~K}$. The concentration ranges of metals varied between 1.0 and $15.0 \mathrm{mg} / \mathrm{dm}^{3}$. To avoid precipitation, the solutions were agitated everytime before use. Batch adsorption experiments (laboratory-scale) were conducted using $1.0-10.0 \mathrm{~g}$ of adsorbent with $50 \mathrm{~cm}^{3}$ of solutions containing $\mathrm{Cr}^{3+}, \mathrm{Ni}^{2+}$ and $\mathrm{Zn}^{2+}$ ions of desired concentrations, respectively, at constant temperature in $250-\mathrm{cm}^{3}$ capped conical flasks. To find out the effect of $\mathrm{pH}$ on adsorption, the initial $\mathrm{pH}$ was adjusted in the range of 2-12 either with $(0.1,1 \mathrm{~N}) \mathrm{HCl}$ or $(0.1,1 \mathrm{~N}) \mathrm{NaOH}$ solutions. To avoid the change in $\mathrm{pH}$ values with time, the resulting solutions were accurately monitored after regular time intervals. Similarly, the effect of agitation time on initial metal concentrations was carried out. Adsorbent (10.0 g) was suspended in the five conical flasks containing $50 \mathrm{~cm}^{3}$ of metal solutions $\left(15 \mathrm{mg} / \mathrm{dm}^{3}\right)$. The conical flasks were uniformly shaken at optimum speed $160 \mathrm{rpm}$ using thermostatic reciprocating shaker for fixed time period from 10 to $420 \mathrm{~min}$ at temperature range from 298 to $313 \mathrm{~K}$. Effects of each factor were determined keeping other variables constant. Samples $\left(5 \mathrm{~cm}^{3}\right)$ were drawn from each flask after a regular time intervals to monitor the progress of adsorption. The sample was then filtered through a Whatman filter paper no. 41 using a vacuum filtration device. The filtrate was analyzed for residual metals concentration determination by (AAS) (AAS-4129, ECIL) using acetylene-air as the fuel-oxidant. The amount of metal adsorbed per unit mass of adsorbent was obtained by using the equation $q_{\mathrm{e}}=\left(C_{\mathrm{o}}-C_{\mathrm{e}}\right) V / m$.

\section{Adsorption isotherms}

The equilibrium data were obtained and analyzed using Langmuir, Freundlich and Temkin isotherm models. The general form of Freundlich model for single solute system is expressed in Eq. (1) [41]:

$q_{\mathrm{e}}=k_{\mathrm{f}} C_{\mathrm{e}}^{1 / n}$

Generally, the logarithmic form of the above equation was used to fit batch equilibrium data. So the linear form of the Freundlich isotherm can be obtained by taking the logarithmic of Eq. (1):

$\log q_{\mathrm{e}}=\log k_{\mathrm{f}}+\frac{1}{n} \log C_{\mathrm{e}}$

The values of the Freundlich constants such as $K_{\mathrm{f}}$ and $1 / n$ can be calculated from intercept and slope of the straight line plot of $\log \left(q_{\mathrm{e}}\right)$ versus $\log \left(C_{\mathrm{e}}\right)$. The linear form of Langmuir isotherm is expressed in Eq. (3) [42]: $\frac{1}{q_{\mathrm{e}}}=\left(\frac{1}{q_{\mathrm{m}} b}\right) \frac{1}{C_{\mathrm{e}}}+\frac{1}{q_{\mathrm{m}}}$

The Langmuir constant such as $\left(q_{\mathrm{m}}\right)$ and $(b)$ values can be obtained from the straight line plot of $\left(1 / q_{\mathrm{e}}\right)$ against (1/ $C_{\mathrm{e}}$ ). A linear form of the Temkin isotherm is expressed in Eq. (4) [43]:

$q_{e}=A+B \ln C_{e}$

where $(A)(\mathrm{mg} / \mathrm{g})=(R T / b) \ln (a)$ and $(B)(\mathrm{L} / \mathrm{mg})=(R T / b)$. The plot $q_{\mathrm{e}}$ against $\ln C_{\mathrm{e}}$ should be linear wherefrom the values of $(A)$ and $(B)$ can be computed from the intercept and slope, respectively. These values of $(A)$ and $(B)$ were subsequently used for estimating Temkin constants $(a)$ and $(b)$.

Kinetic models

The kinetic data were modelled using Pseudo-second-order and Weber and Morris intraparticle diffusion equations that correlates solute uptake during adsorption process.

\section{The Pseudo-second-order equation}

The pseudo-second-order adsorption rate equation is expressed in Eq. (5) [44]

$\frac{t}{q_{t}}=\frac{1}{h}+\frac{t}{q_{\mathrm{e}}}$

where $h$ is the initial adsorption rate as $t \rightarrow 0$ i.e. $h=k_{2} q_{\mathrm{e}}^{2}$. According to the above equation, a plot of $\left(t / q_{t}\right)$ against $(t)$ will yield a straight line with slope $\left(1 / q_{\mathrm{e}}\right)$ and intercept $(1 / h)$.

\section{Weber and Morris intraparticle diffusion equation}

Weber and Morris intraparticle diffusion equation is expressed as follows in Eq. (6) [15]:

$q_{t}=k_{\mathrm{id}} t^{1 / 2}+C$

Accordingly, the constants $(C)$ and $\left(K_{\text {id }}\right)$ were interpreted from intercept and slope of the respective plot.

\section{Thermodynamics studies}

The thermodynamic constants, entropy change $(\Delta S)$ and enthalpy change $(\Delta H)$, were computed from the slope and intercept of the Van't Hoff plots. The apparent equilibrium constant $\left(k_{\mathrm{C}}\right)$ of the adsorption is defined as:

$k_{\mathrm{C}}=\frac{C_{\mathrm{AD}}}{C_{\mathrm{e}}}$

The values of $\Delta S$ and $\Delta H$ were calculated from Eq. (8). The Gibbs free energy was calculated to determine the feasibility of adsorption process using the Eq. (9) 
$\ln k_{\mathrm{C}}=\frac{\Delta S}{R}-\frac{\Delta H}{R T}$

$\Delta G=\Delta H-T \Delta S$

\section{Results and discussion}

\section{Structural characterization of CA/TPC}

Figure 1 shows the synthesis route of cellulose acetate-tin (IV) phosphate composite material. In order to obtained better ion exchange capacity, a number of samples of $\mathrm{CA} /$
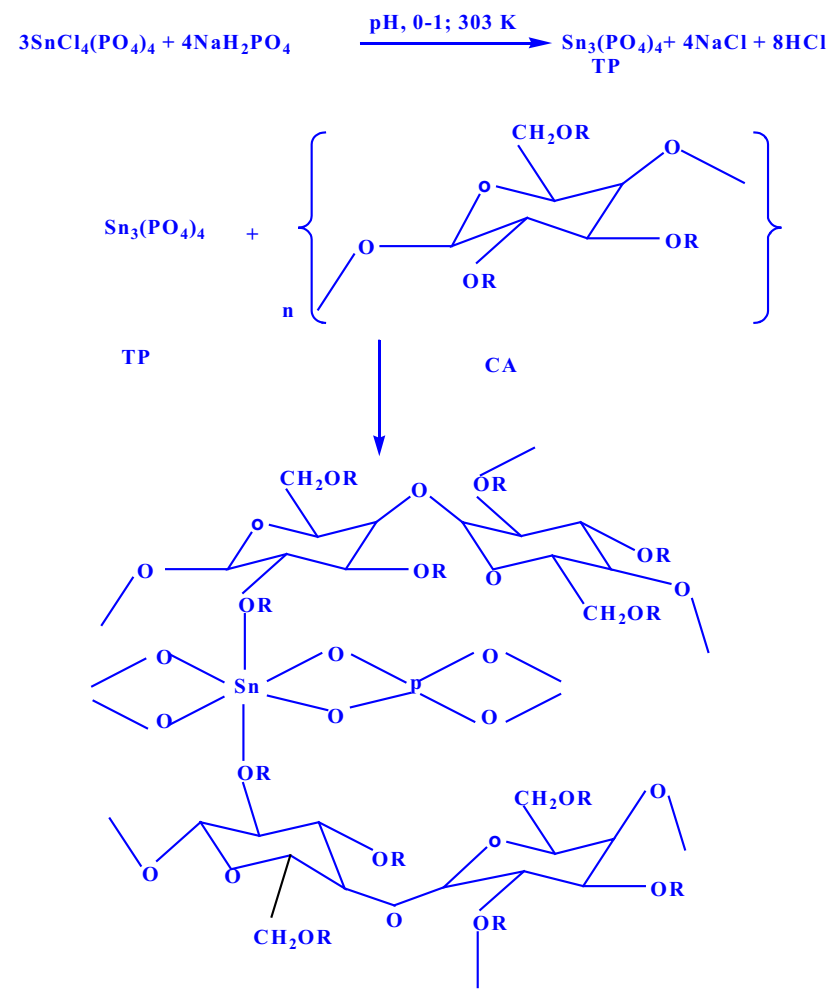

CA/TPIE

$\mathrm{R}=\mathrm{CH}_{3} \mathrm{CO}$

Fig. 1 Schematic depiction of synthesis route for CA/TPC adsorbent [32]
TPC were synthesized by sol-gel mixing method. Table 3 illustrates that the ion exchange capacity of CA/TPC was influenced by mixing ratio, concentration of reagents and system $\mathrm{pH}$. As the ratio of anionic part (sodium dihydrogen phosphate) in the reaction mixture was increased, the ion exchange capacity of CA/TPC was increased because the replaceable hydrogen groups were bound to this group ( $\mathrm{PO}_{4}{ }^{3-}$ ionogenic group) [40]. Further, the CA/TPC material has shown best synthetic utility at $\mathrm{pH} 1$. Among various samples synthesized, sample- 5 has better $\mathrm{Na}^{+}$ion exchange capacity and good reproducible behavior, (Table 3). Therefore, it was selected for detailed studies. The improvement in ion exchange capacity of CA/TPC may be due to the binding of cellulose acetate with inorganic moiety (tin (IV) phosphate). The surface morphology of CA/TPC before and after $\mathrm{Cr}^{3+}, \mathrm{Ni}^{2+}$ and $\mathrm{Zn}^{2+}$ adsorptions was determined by scanning electron microscopy (SEM) and was presented in Fig. 2a-d, respectively. Figure 2a shows semi-crystalline nature of surfaces particles with few sharp edges that become slightly rough after the metal ion adsorptions [32]. Figure 3 shows X-ray diffraction (XRD) pattern of CA/TPC. No sharp peaks were obtained that confirmed the non-crystalline nature of CA/TPC. The infrared spectrum of CA/TPC is shown in Fig. 4a. The broad peak at $3,499 \mathrm{~cm}^{-1}$ was due to the presence of $-\mathrm{OH}$ group of water of crystallization. A peak at $1,630 \mathrm{~cm}^{-1}$ is also indicative of presence of strongly bonded $-\mathrm{OH}$ groups. The absorption band at $1,710 \mathrm{~cm}^{-1}$ was aroused due to the carbonyl group of cellulose acetate part. The broad peak at $1,020 \mathrm{~cm}^{-1}$ was assigned to the presence of $\mathrm{PO}_{4}{ }^{3-}$ and $\mathrm{H}_{2} \mathrm{PO}_{4}{ }^{-}$groups, respectively [35]. The absorption band at $470 \mathrm{~cm}^{-1}$ may be due to the superposition of metal-oxygen stretching vibrations suggested the combination between cellulose acetate and tin (IV) phosphate [32]. Figure $4 \mathrm{~b}-\mathrm{d}$ show that the intensity and position of absorption band at $1,020 \mathrm{~cm}^{-1}$ has been changed due to $\mathrm{Cr}^{3+}, \mathrm{Ni}^{2+}$ and $\mathrm{Zn}^{2+}$ adsorptions. In addition, the peaks at $3,499 \mathrm{~cm}^{-1}$ were also subside after $\mathrm{Cr}^{3+}, \mathrm{Ni}^{2+}$ and $\mathrm{Zn}^{2+}$ adsorptions indicating the involvement of $-\mathrm{OH}, \mathrm{PO}_{4}{ }^{3-}$ and $\mathrm{H}_{2} \mathrm{PO}_{4}{ }^{-}$ groups in the adsorption of $\mathrm{Cr}^{3+}, \mathrm{Ni}^{2+}$ and $\mathrm{Zn}^{2+}$ ions. The EDX spectrum of CA/TPC before and after $\mathrm{Cr}^{3+}, \mathrm{Ni}^{2+}$ and $\mathrm{Zn}^{2+}$ ions adsorptions was recorded and shown in Fig. 5a-d.

Table 3 Synthesis of CA/TPC at different conditions of system

\begin{tabular}{|c|c|c|c|c|c|c|c|}
\hline S. no. & $\begin{array}{l}\text { Cellulose acetate } \\
\text { (M) }\end{array}$ & $\begin{array}{l}\text { Tin (IV) chloride } \\
\text { (M) }\end{array}$ & $\begin{array}{l}\text { Sodium dihydrogen } \\
\text { phosphate }(\mathrm{M})\end{array}$ & $\begin{array}{l}\text { Mixing ratio } \\
(\mathrm{v} / \mathrm{v})\end{array}$ & $\begin{array}{l}\mathrm{pH} \\
(-)\end{array}$ & $\begin{array}{l}\text { Temperature } \\
(\mathrm{K})\end{array}$ & $\begin{array}{l}\text { IEC } \\
\left(\text { meq g }^{-1}\right)\end{array}$ \\
\hline 1. & 0.1 & 0.1 & 0.1 & $1: 1: 1$ & 0.5 & $303 \pm 2$ & 0.61 \\
\hline 2. & 0.1 & 0.1 & 0.1 & $1: 1: 1$ & 1.0 & $303 \pm 2$ & 1.15 \\
\hline 3. & 0.2 & 0.1 & 0.1 & $1: 1: 1$ & 1.0 & $303 \pm 2$ & 1.07 \\
\hline 4. & 0.2 & 0.1 & 0.1 & $1: 2: 1$ & 1.0 & $303 \pm 2$ & 1.24 \\
\hline 5. & 0.2 & 0.1 & 0.1 & $1: 1: 2$ & 1.0 & $303 \pm 2$ & 1.51 \\
\hline
\end{tabular}

IEC ion exchange capacity for $\mathrm{Na}^{+}$ions 

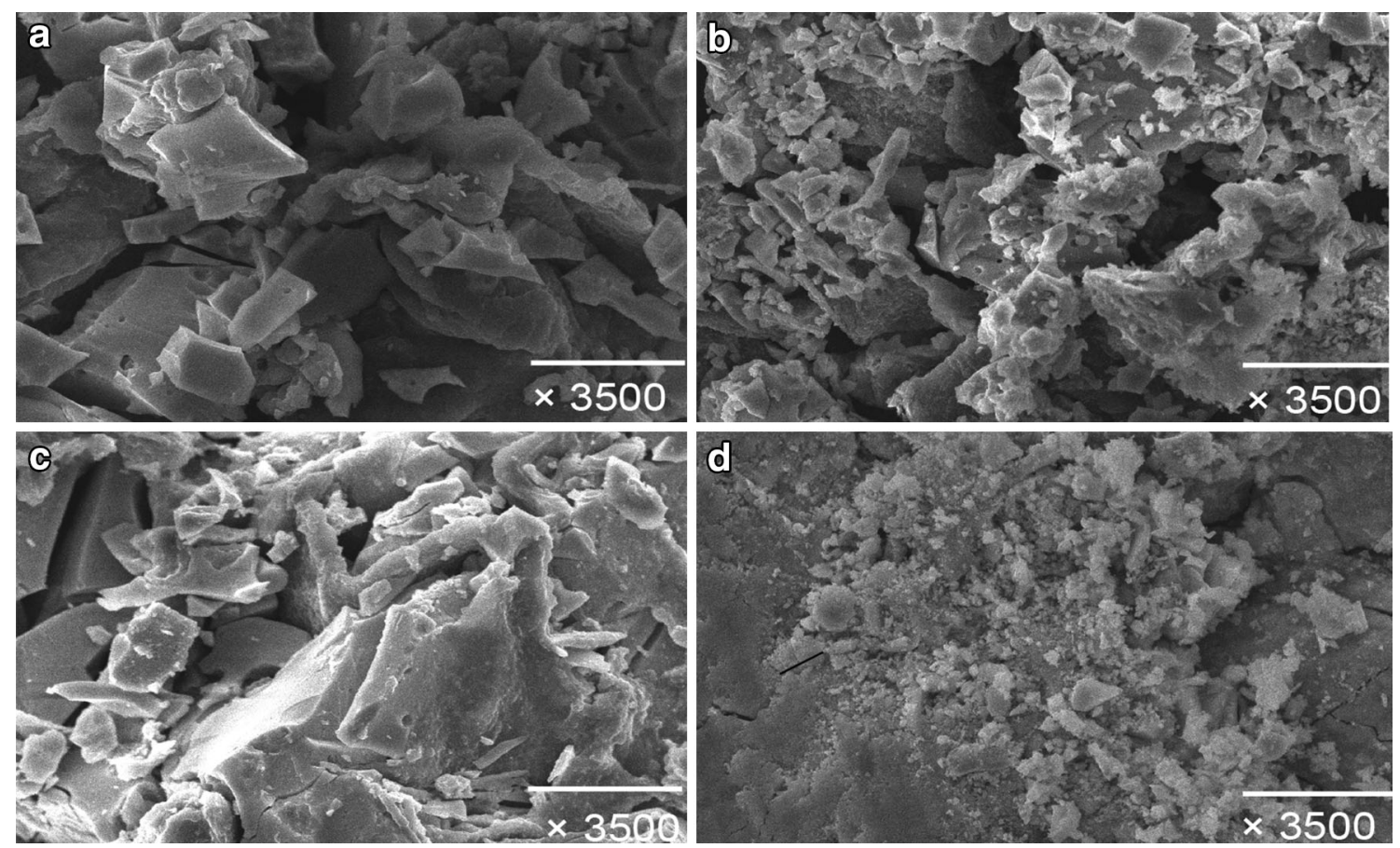

Fig. 2 SEM image of CA/TPC a before adsorption; b after $\mathrm{Cr}^{3+}$ adsorption; $\mathbf{c ~ N i}{ }^{2+}$ adsorption; and $\mathbf{d} \mathrm{Zn}^{2+}$ adsorption

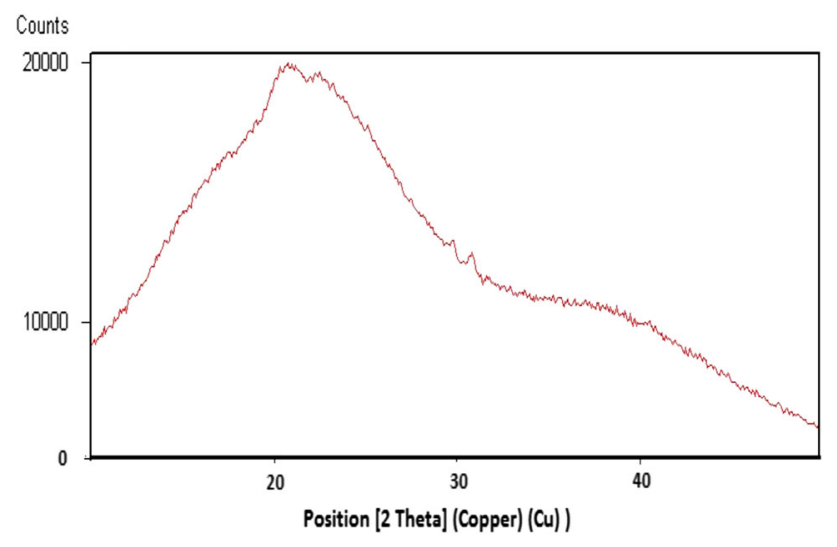

Fig. 3 XRD spectrum of CA/TPC

Figure 5a illustrates that tin, oxygen and phosphorous were the main constituents present in CA/TPC material. As shown in Fig. 5b-d, some peaks due to chromium, nickel and zinc metals adsorptions were observed in the EDX spectrum of $\mathrm{CA} / \mathrm{TPC}$. Figure $5 \mathrm{e}$ shows the elemental (wt $\%$ ) composition of CA/TPC surface.

\section{Breakthrough studies}

$1.0 \mathrm{~g}$ of CA/TPC has been taken in glass column with glass wool support at the bottom. One liter each of $\mathrm{Cr}^{3+}, \mathrm{Ni}^{2+}$ and $\mathrm{Zn}^{2+}$ solutions of initial concentration $15 \mathrm{mg} / \mathrm{dm}^{3}\left(C_{\mathrm{o}}\right)$ were passed through a column separately at flow rate of $1 \mathrm{~cm}^{3} / \mathrm{min}$. The eluent was collected in $50 \mathrm{~cm}^{3}$ fractions, and the amount of $\mathrm{Cr}^{3+}, \mathrm{Ni}^{2+}$ and $\mathrm{Zn}^{2+}(C)$ was determined in each fraction by AAS. The breakthrough curves for $\mathrm{Cr}^{3+}, \mathrm{Ni}^{2+}$ and $\mathrm{Zn}^{2+}$ ions were obtained by plotting $\mathrm{C} /$ $C_{\mathrm{o}}$ versus volume of the eluent, Fig. 6 . The observed breakthrough capacities for $\mathrm{Cr}^{3+}, \mathrm{Ni}^{2+}$ and $\mathrm{Zn}^{2+}$ in each of the metal solutions were $3.0,4.0$ and $3.5 \mathrm{mg} / \mathrm{g}$., whereas the exhaustive capacity for the same metal ions was 7.5, 9.0 and $8.5 \mathrm{mg} / \mathrm{g}$, respectively.

\section{Effect of adsorbent dosage}

The adsorption of heavy metals, as a function of CA/TPC dosage, was studied. Figure 7 shows the effect of CA/TPC dosages on the initial concentrations of $\mathrm{Cr}^{3+}, \mathrm{Ni}^{2+}$ and $\mathrm{Zn}^{2+}$ ions. Amount of adsorbent was varied from 1.0 to $10.0 \mathrm{~g} / 50 \mathrm{~cm}^{3}$ (with particle size $<20 \mathrm{mesh}$ ) and equilibrated for $1 \mathrm{~h}$, keeping a $\mathrm{pH}$ of each metal solution of 6 . The $\mathrm{Cr}^{3+}$ ion concentration was decreased from 0.99 to $0.15 \mathrm{mg} / \mathrm{dm}^{3}$ with increase in adsorbent loading from 1.0 to $10.0 \mathrm{~g} / 50 \mathrm{~cm}^{3}$ and then became almost constant, whereas the concentrations of $\mathrm{Zn}^{2+}$ and $\mathrm{Ni}^{2+}$ ions were found to be decreased from 0.65 to 0.1 and 0.3 to $0.01 \mathrm{mg} /$ $\mathrm{dm}^{3}$, respectively, for a similar increase in adsorbent dose. The results indicates that $10.0 \mathrm{~g}$ of CA/TPC dose was sufficient for the optimum removal of $\mathrm{Cr}^{3+}, \mathrm{Ni}^{2+}$ and $\mathrm{Zn}^{2+}$ ions. In order to facilitate analysis and comparison of the 

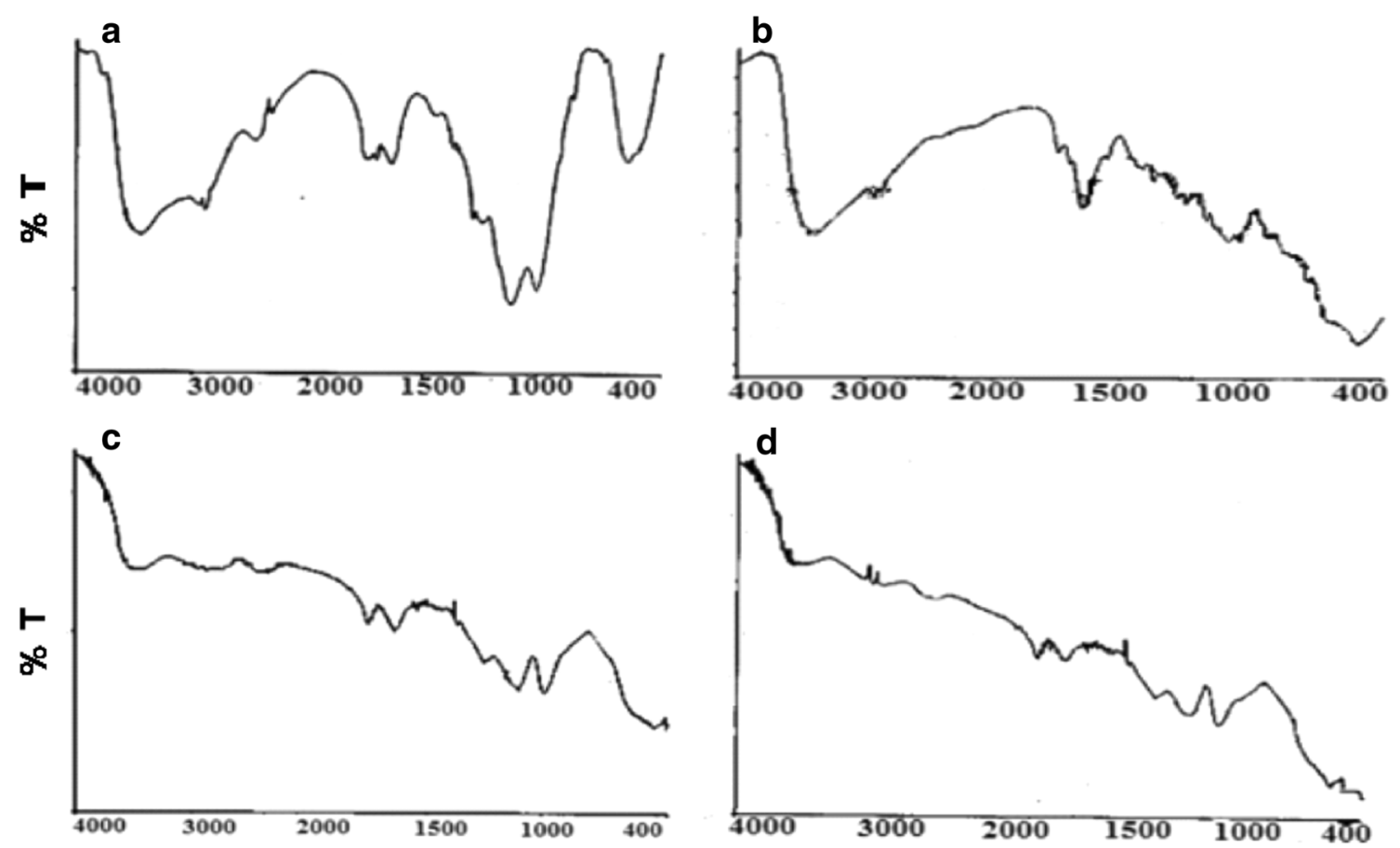

Fig. 4 a FT-IR spectrum of CA/TPC before adsorption; $\mathbf{b}$ after $\mathrm{Zn}^{2+}$ adsorption; $\mathbf{c ~} \mathrm{Cr}^{3+}$ adsorption; and $\mathbf{d ~ N i}{ }^{2+}$ adsorption
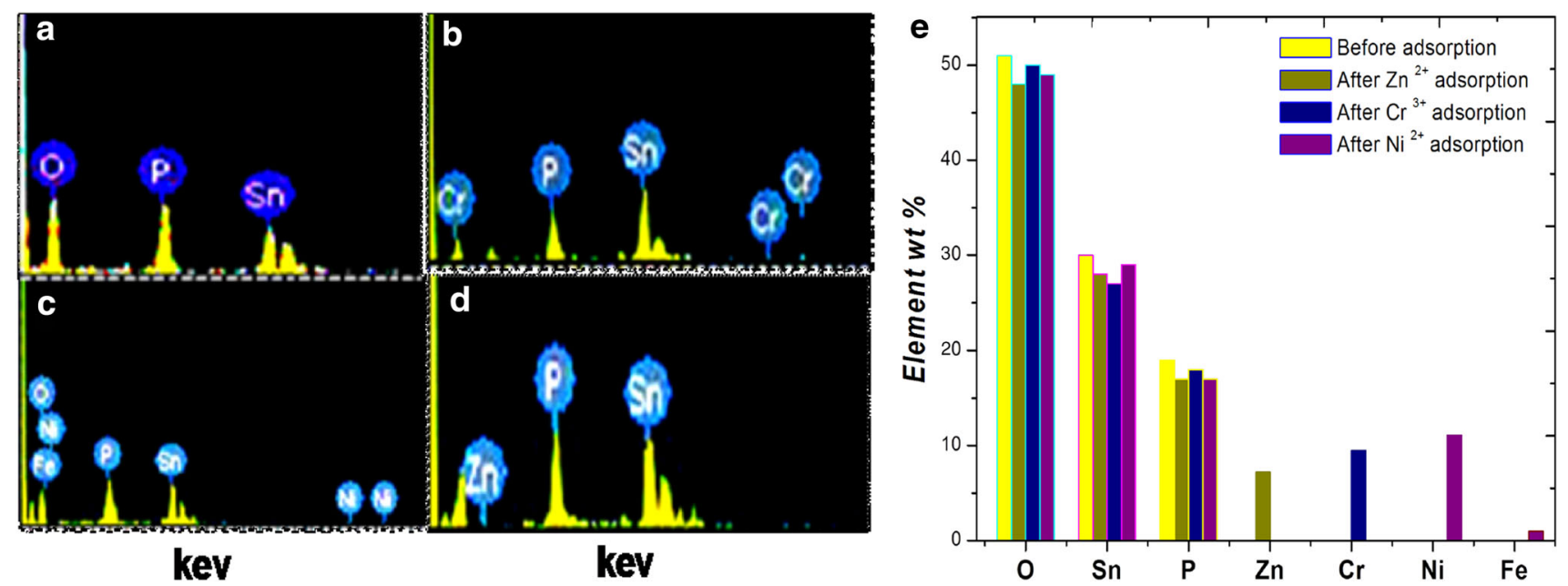

Fig. 5 Energy-dispersive X-ray spectrum of CA/TPC a before adsorption; $\mathbf{b}$ after $\mathrm{Cr}^{3+}$ adsorption; $\mathbf{c} \mathrm{Ni}^{2+}$ adsorption; $\mathbf{d} \mathrm{Zn}^{2+}$ adsorption; and e EDX plot

experimental data, the remaining experiments were performed with $10.0 \mathrm{~g} / 50 \mathrm{~cm}^{3}$ of CA/TPC dose for each metal ions.

\section{Effect of agitation time}

The removal of heavy metals by CA/TPC as a function of contact time was investigated. Contact time was varied in the range of 10-420 $\mathrm{min}$ at the given temperatures, (298, 308 and $313 \mathrm{~K}$ ). As shown in Fig. 8a-c, the value of $q$ was increased as the agitation time and temperature conditions increased, until equilibrium was reached. The adsorptions of $\mathrm{Cr}^{3+}, \mathrm{Ni}^{2+}$ and $\mathrm{Zn}^{2+}$ ions on CA/TPC were rapid for the first $50 \mathrm{~min}$ and remained almost constant beyond $50 \mathrm{~min}$ at all the given temperatures. However, complete equilibrium for $\mathrm{Cr}^{3+}$ adsorption was attained in $60 \mathrm{~min}$, and for $\mathrm{Ni}^{2+}$ and $\mathrm{Zn}^{2+}$, it was attained in $120 \mathrm{~min}$ with initial concentrations of each metals $15 \mathrm{mg} / \mathrm{dm}^{3}$. There were no significant changes in $\mathrm{Cr}^{3+}, \mathrm{Ni}^{2+}$ and $\mathrm{Zn}^{2+}$ uptake observed by CA/TPC after $420 \mathrm{~min}$. The complete adsorption of $\mathrm{Cr}^{3+}$ ions requires less residence time $(60 \mathrm{~min})$ as compared to $\mathrm{Ni}^{2+}$ and $\mathrm{Zn}^{2+}$ ions (120 min). Therefore, the 


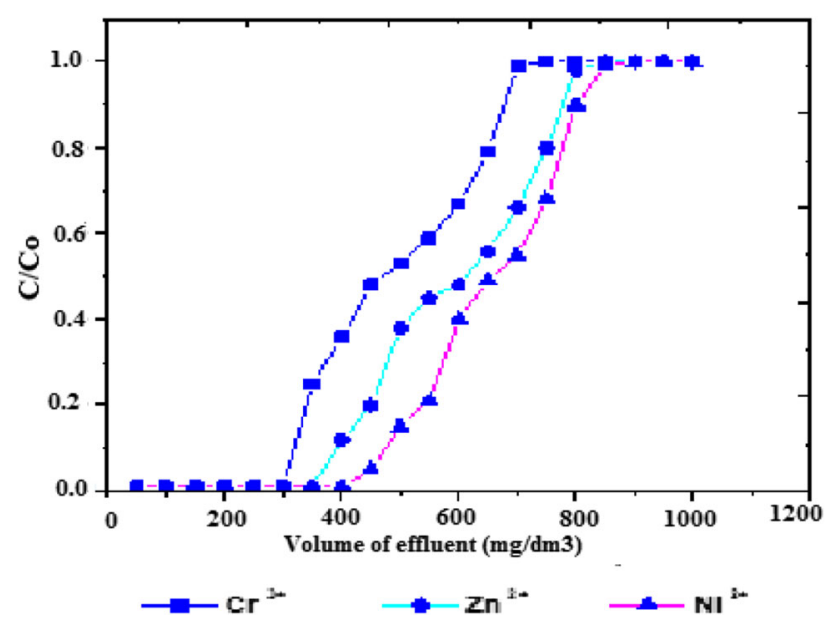

Fig. 6 Breakthrough curves for $\mathrm{Ni}^{2+}, \mathrm{Zn}^{2+}$ and $\mathrm{Cr}^{3+}$ adsorption onto CA/TPC

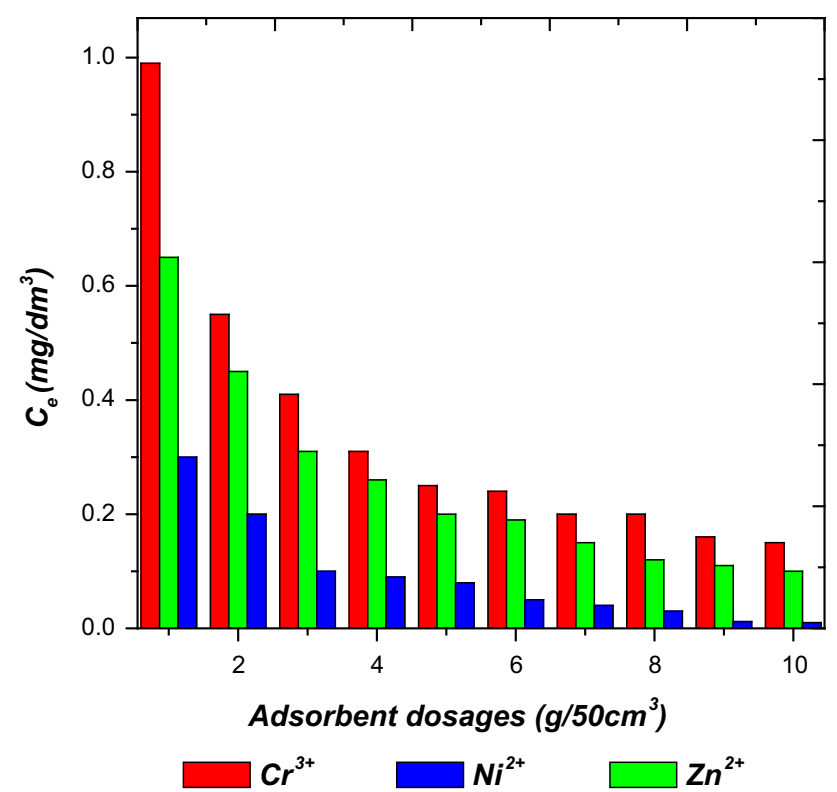

Fig. 7 Effect of adsorbent dosage (conc. $15-\mathrm{mg} / \mathrm{dm}^{3}$; pH 6.0; time $1 \mathrm{~h})$

period of $60 \mathrm{~min}$ was considered as the optimum time for $\mathrm{Cr}^{3+}$, and for the $\mathrm{Ni}^{2+}$ and $\mathrm{Zn}^{2+}$ ions, adsorptions optimum time was $120 \mathrm{~min}$, respectively. $F$ test analysis illustrates that agitation time and temperature conditions have shown more significant effect on the $\mathrm{Ni}^{2+}$ uptake as compared to $\mathrm{Cr}^{3+}$ and $\mathrm{Zn}^{2+}$ ions due to better $F$ value 15.117 (Tables $\mathrm{S} 1(\mathrm{a}-\mathrm{c})$ shown in supplementary material).

\section{Effect of $\mathrm{pH}$ of solution}

Hydronium ion concentration is an important parameter affecting the ion exchange process. This is partly because hydrogen ions themselves are strongly competing adsorbate and the solution $\mathrm{pH}$ influences the ionization of surface functional groups. Figure 9 shows the effects of $\mathrm{pH}$ (in the range of 2-12) on adsorption of $\mathrm{Cr}^{3+}, \mathrm{Ni}^{2+}$ and $\mathrm{Zn}^{2+}$ ions by CA/TPC at a fixed concentration $(15 \mathrm{mg} /$ $\mathrm{dm}^{3}$ ) and time of $1 \mathrm{~h}$. The $\mathrm{pH}$ of the solution was controlled using buffer solution. The residual concentrations of $\mathrm{Ni}^{2+}$ and $\mathrm{Zn}^{2+}$ ions were found to be $\sim 0.5 \mathrm{mg} / \mathrm{dm}^{3}$ between $\mathrm{pH} 4-6$ and reached to 6.9 and $8.8 \mathrm{mg} / \mathrm{dm}^{3}$ as $\mathrm{pH}$ increased to 12 while the residual concentration for $\mathrm{Cr}^{3+}$ ion was $\sim 1.0 \mathrm{mg} / \mathrm{dm}^{3}$ at $\mathrm{pH} 3$ and increased to $12.1 \mathrm{mg} /$ $\mathrm{dm}^{3}$ when $\mathrm{pH}$ reached to 12 . The results show that CA/TPC has taken maximum $\mathrm{Cr}^{3+}$ from the solution at $\mathrm{pH} 3$ while $\mathrm{Ni}^{2+}$ and $\mathrm{Zn}^{2+}$ ions were effectively adsorbed in the range of $\mathrm{pH} 4-6$. The removal efficiency of CA/TPC for all metals was diminished at higher $\mathrm{pH}$ values because the hydrolysis of the metal ions occurs by the formation of metal hydroxides, which compete with the metal ion uptake by the CA/TPC $[1,45]$. The effects of solution $\mathrm{pH}$ (in the range of 2-12) on the initial metal concentrations $\left(15 \mathrm{mg} / \mathrm{dm}^{3}\right)$ without using CA/TPC dosages under similar conditions were investigated. Figure 10 shows that the residual concentrations of $\mathrm{Cr}^{3+}, \mathrm{Ni}^{2+}$ and $\mathrm{Zn}^{2+}$ ions were found to be $14.4,14.1$ and $14.6 \mathrm{mg} / \mathrm{dm}^{3}$ when $\mathrm{pH}$ reached to $7.5,9.0$ and 9.5 but decreased sharply to $0.5,0.2$ and $3.7 \mathrm{mg} / \mathrm{dm}^{3}$ as $\mathrm{pH}$ was increased to 12 . Thus, at higher $\mathrm{pH}$, no more free metals were available for binding with $\mathrm{CA} /$ TPC.

\section{Equilibrium study}

The adsorption isotherms description for $\mathrm{Cr}^{3+}, \mathrm{Ni}^{2+}$ and $\mathrm{Zn}^{2+}$ ions on CA/TPC at given temperatures from 298 to $313 \mathrm{~K}$ has been studied. As shown in Fig. 11a-c, the adsorption capacities of CA/TPC for three metals were found to be increased with rise in temperature as well as initial $\mathrm{Cr}^{3+}, \mathrm{Ni}^{2+}$ and $\mathrm{Zn}^{2+}$ concentrations. A comparison of adsorption isotherms at 298, 308 and $313 \mathrm{~K}$ indicates that $\mathrm{Cr}^{3+}, \mathrm{Ni}^{2+}$ and $\mathrm{Zn}^{2+}$ adsorptions by CA/TPC were significantly affected by increase in the temperature. Maximum adsorption capacities of CA/TPC for $\mathrm{Cr}^{3+}, \mathrm{Ni}^{2+}$ and $\mathrm{Zn}^{2+}$ ions were found to be $31.5,43.7$ and $43.4 \mathrm{mg} / \mathrm{g}$ at higher temperature, $313 \mathrm{~K}$ that shows endothermic nature of the process. The initial sharp rise in the isotherm indicates the availability of readily accessible sites for adsorption. However, site saturation occurs as the $\mathrm{Cr}^{3+}, \mathrm{Ni}^{2+}$ and $\mathrm{Zn}^{2+}$ concentration increased and a plateau was reached indicating that no more sites remain available for adsorption. $F$ test analysis predicts that initial $\mathrm{Ni}^{2+}$ concentration and temperature conditions have more significantly affected $\mathrm{Ni}^{2+}$ uptake with good $F$ test value, 12.857 as compared to $\mathrm{Cr}^{3+}$ and $\mathrm{Zn}^{2+}$ ions, (Table S2 (a-c) shown in supplementary material). The equilibrium data obtained from Fig. 11a-c were applied to the Eqs. (2), (3) 


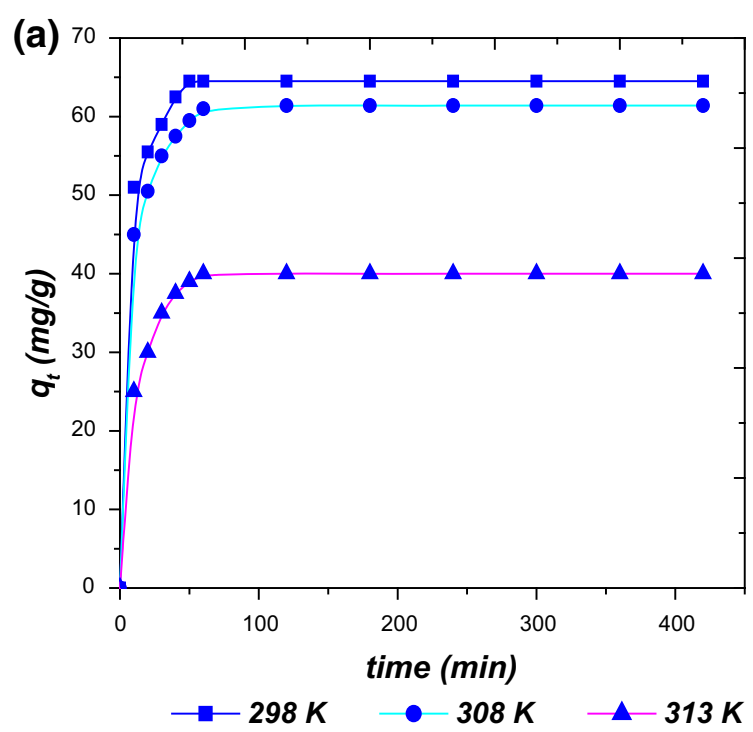

(b)

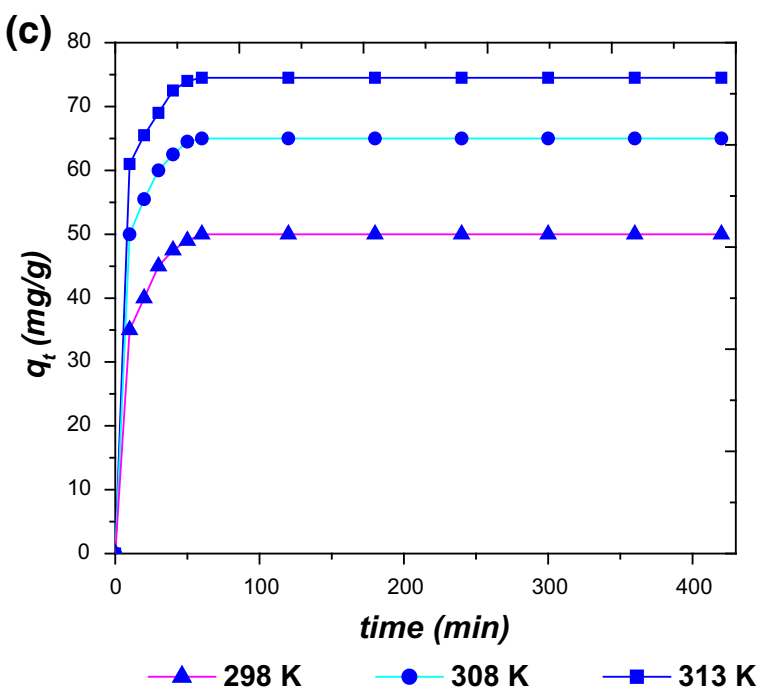

Fig. 8 a Effect of agitation time on $\mathrm{Cr}^{3+}$ adsorption (conc. $15 \mathrm{mg} / \mathrm{dm}^{3}$; AD $10.0 \mathrm{~g} ; \mathrm{pH}$ 6.0). b Effect of agitation time on $\mathrm{Ni}^{2+}$ adsorption (conc. $15-\mathrm{mg} / \mathrm{dm}^{3}$; AD $10.0 \mathrm{~g}$; pH 6.0). c Effect of agitation time on $\mathrm{Zn}^{2+}$ adsorption (conc. $15-\mathrm{mg} / \mathrm{dm}^{3} ; \mathrm{AD} 10.0 \mathrm{~g} ; \mathrm{pH} 6.0$ )

and (4), respectively, for the verification of the Freundlich, Langmuir and Temkin isotherm models, respectively. The results of Freundlich, Langmuir and Temkin linear plots are shown in (Figs. S3,4,5 (a-c) in the supplementary material). The Freundlich, Langmuir and Temkin constants values along with their correlation coefficients $\left(R^{2}\right)$ are compiled in Table 4. Good correlation coefficients $\left(R^{2}>0.99\right)$ for $\mathrm{Cr}^{3+}, \mathrm{Ni}^{2+}$ and $\mathrm{Zn}^{2+}$ ions at given temperatures indicated the applicability of Langmuir model in the present study. The values of $q_{\mathrm{m}}$ calculated by the Langmuir isotherm were all close to experimental values at all given temperatures. These facts suggested that $\mathrm{Cr}^{3+}$, $\mathrm{Ni}^{2+}$ and $\mathrm{Zn}^{2+}$ were adsorbed in the form of monolayer coverage on the surface of the adsorbent. To determine the nature of adsorption process whether favorable or unfavorable, the dimensionless constant separation term $\left(R_{\mathrm{L}}\right)$

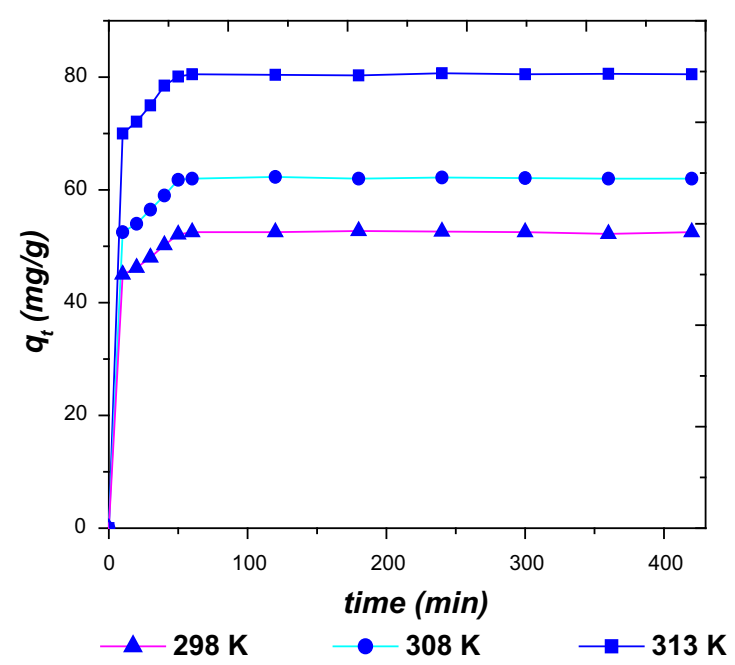




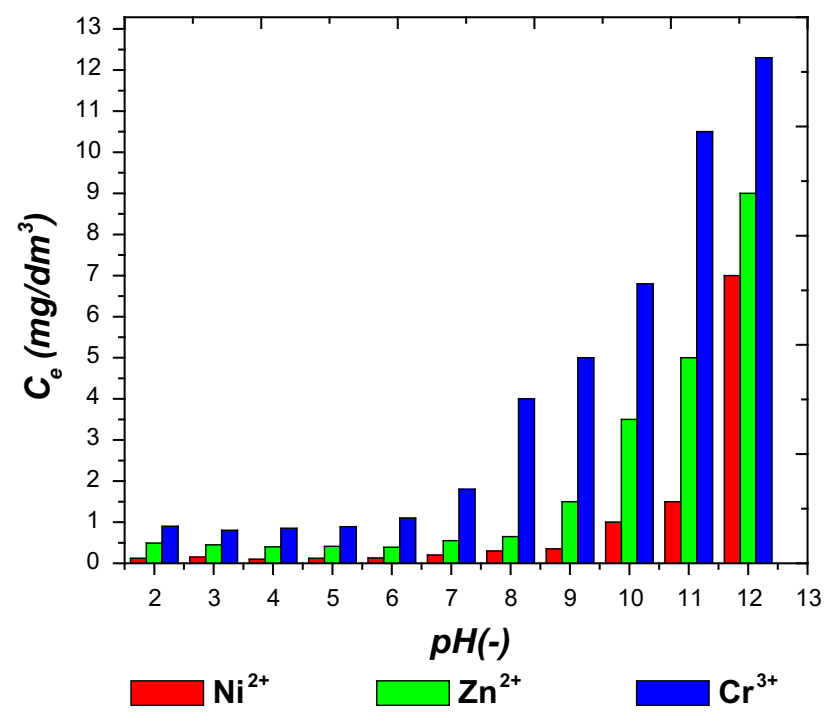

Fig. 9 Effect of $\mathrm{pH}$ on residual concentrations of metals (conc. $15-\mathrm{mg} / \mathrm{dm}^{3}$; $\mathrm{pH}$ 6.0; AD $10.0 \mathrm{~g}$; agitation time $1 \mathrm{~h}$ )

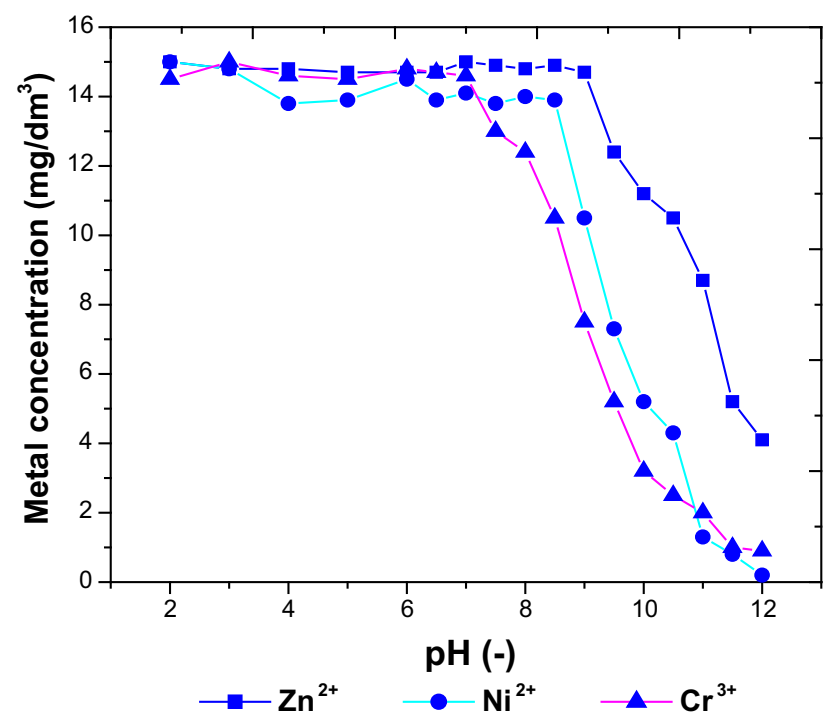

Fig. 10 Effect of $\mathrm{pH}$ on metal concentrations without CA/TPC dosage (conc. $15 \mathrm{mg} / \mathrm{dm}^{3}$; agitation time, $2 \mathrm{~h}$ for $\mathrm{Ni}^{2+}$ and $\mathrm{Zn}^{2+} ; 1 \mathrm{~h}$ for $\mathrm{Cr}^{3+}$ )

uptake values for the removal of $\mathrm{Cr}^{3+}, \mathrm{Ni}^{2+}$ and $\mathrm{Zn}^{2+}$ are shown in Fig. 8a-c. The data were analyzed using pseudosecond-order kinetic model (Figs. S1(a-c) shown in supplementary material). Kinetic parameters and correlation coefficients $\left(R^{2}\right)$ are summarized in Table 6 . The $R^{2}$ values for pseudo-second-order model for $\mathrm{Cr}^{3+}, \mathrm{Ni}^{2+}$ and $\mathrm{Zn}^{2+}$ were all found to be in the range $(0.99-1)$ at all given temperatures. The calculated $q_{\text {e(cal.) }}$ values at given temperatures were all very close to the experimental values $q_{\text {e(exp.) }}$ as predicted by Chi-square $\left(\chi^{2}\right)$ test. Further, on increasing the temperature, there were no significant differences observed between the experimental as well as calculated adsorption capacities $\left(q_{\mathrm{e}}\right)$ at 0.99 level of significance for all the metals. Accordingly, the adsorptions of three metals on CA/TPC have been well described by the pseudo-second-order model. The present data were also examined by the Weber and Morris intraparticle diffusion model, Eq. (6) (Figs. S7(a-c) shown in supplementary material), represents plots of $\left(q_{t}\right)$ versus $\left(t^{1 / 2}\right)$ for three metal ions at given temperatures, whereas the results of the corresponding linear correlation analysis are tabulated in Table 6 . The present data exhibit multilinear plots, which shows that the adsorption process was governed by two or more steps. In the given figures, all of the curves for $\mathrm{Cr}^{3+}$, $\mathrm{Ni}^{2+}$ and $\mathrm{Zn}^{2+}$ follow same features, in which the initial steep portion followed by a gradual linear portion was observed. The first linear segment (phase 1) at all the temperature for $\left(t^{0.5}=3.16-7.74\right)$ was observed due to the immediate utilization of the most readily available adsorbing sites on the adsorbent surface, and the second phase (phase 2) for $\left(t^{0.5}=7.74-20.4\right)$ was attributed to very slow diffusion of the adsorbate from the surface site into the inner pores. The values of $k_{\mathrm{id} 1}$ and $k_{\mathrm{id} 2}$ (for phase 1 and 2, respectively) obtained from the slope of linear plots are listed in Table 6. Higher values of $k_{\mathrm{id} 1}$ as compared to $k_{\mathrm{id} 2}$ for $\mathrm{Cr}^{3+}, \mathrm{Ni}^{2+}$ and $\mathrm{Zn}^{2+}$ ions at all given temperature indicated the rapid boundary layer diffusion (phase 1) that was followed by a slow intraparticle diffusion (phase 2). Furthermore, the second segment of the lines (phase 2), describing the intraparticle diffusion, does not pass through the origin indicates that the intraparticle diffusion was not only the rate-limiting step. The observed deviations in straight lines in Weber and Morris model were attributed to the difference in the rate of mass transfer in initial and final stages of adsorption [46].

Thermodynamics studies

The experimental data obtained at given temperatures (298-318 K) and concentrations $\left(2-15 \mathrm{mg} / \mathrm{dm}^{3}\right)$ were used in calculating the thermodynamic parameters such as gibbs free energy change $(\Delta G)$, enthalpy change $(\Delta H)$ and entropy change $(\Delta S)$. Figs. S6 (a-c) (given in supplementary materials) shows the linear plots of $\ln k_{\mathrm{c}}$ versus $1 / T$ for different metal concentrations $\left(2-15 \mathrm{mg} / \mathrm{dm}^{3}\right)$. The free energy of the process at all given temperatures and different metal concentrations was found to be negative for all the metal adsorption processes. The negative values of $\Delta G$ were attributed due to the fact that all metal adsorption processes were spontaneous and the degrees of spontaneity of the reactions were increased with rise in temperatures in all cases. The positive value of $\Delta S$ suggests increased randomness at the solid/solution interface [47]. This may have been aroused by the release of water molecules, ion 

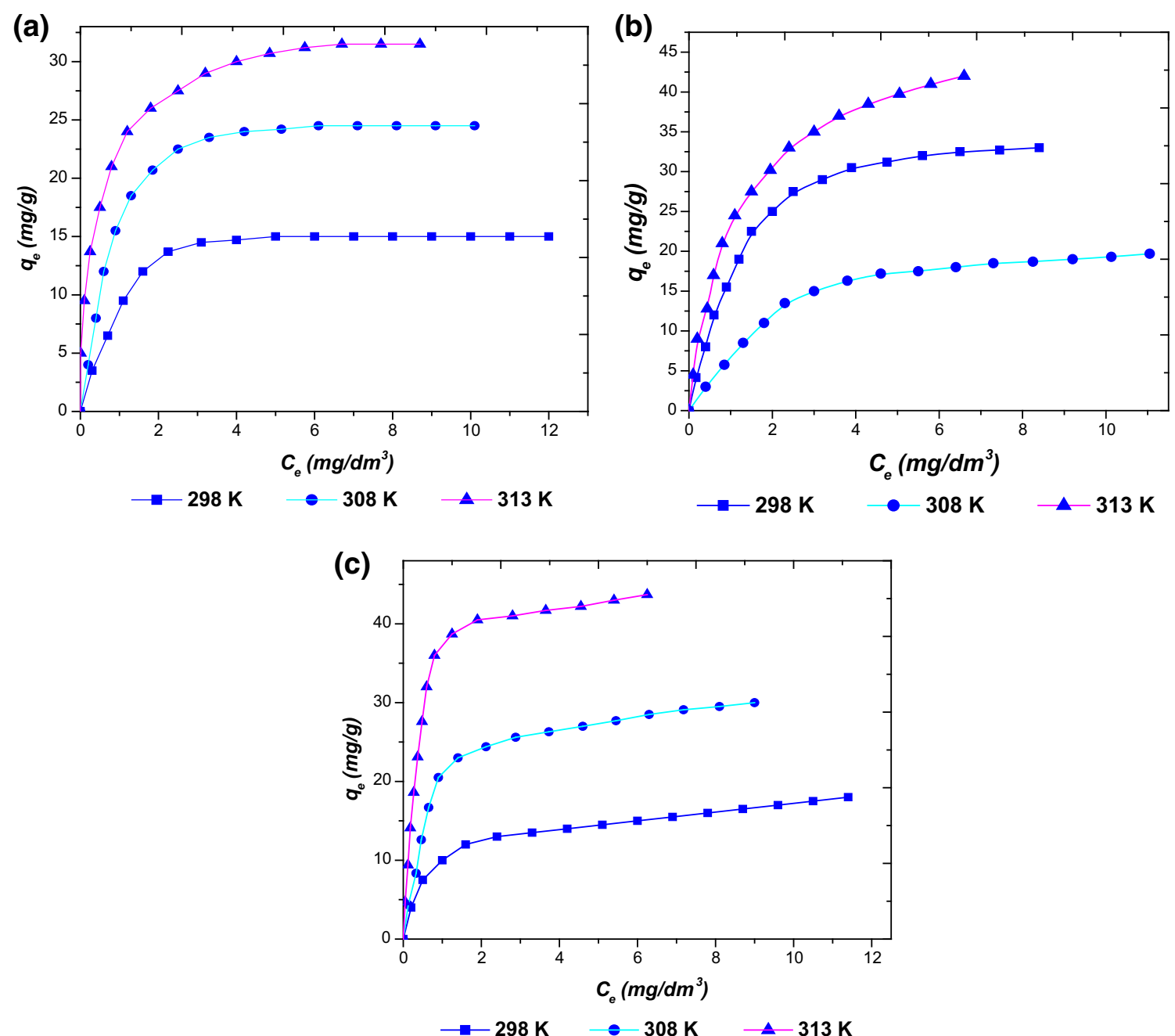

Fig. 11 a Adsorption isotherm for $\mathrm{Cr}^{3+}$ adsorption (AD $10.0 \mathrm{~g}$; initial $\mathrm{pH} 4$ and 6.0; agitation time $1 \mathrm{~h}$ ). b Adsorption isotherm for $\mathrm{Ni}^{2+}$ adsorption (AD $10.0 \mathrm{~g}$; initial $\mathrm{pH} 3.0$; agitation time $2 \mathrm{~h}$ ). c Adsorption isotherm for $\mathrm{Zn}^{2+}$ adsorption (AD $10.0 \mathrm{~g}$; initial pH 4 and 6.0; agitation time $2 \mathrm{~h}$ )

increasing the number of cycle and $\mathrm{pH}$ value, the metal desorption's were decreased. At $\mathrm{pH} 1$, amount of metals desorbed were in the order of $\mathrm{Ni}^{2+}>\mathrm{Zn}^{2+}>\mathrm{Cr}^{3+}$. As expected from highest electronegativity value of $\mathrm{H}^{+}$ions (EN. $\sim 2.20)$ in comparison with $\mathrm{Cr}^{3+}(\mathrm{EN} . \sim 1.6), \mathrm{Ni}^{2+}$ (EN. $~ 1.8)$ and $\mathrm{Zn}^{2+}(\mathrm{EN} . \sim 1.6)$ ions, the $\mathrm{H}^{+}$ions were able to replace $\mathrm{Cr}^{3+}, \mathrm{Ni}^{2+}$ and $\mathrm{Zn}^{2+}$ ions of CA/TPC [48]. This indicates that $\mathrm{Cr}^{3+}, \mathrm{Ni}^{2+}$ and $\mathrm{Zn}^{2+}$ adsorptions on CA/TPC were due to the ion exchange mechanism. The adsorption efficiencies of CA/TPC for all the metal ions were maintained after four consecutive cycles of adsorption/desorption process. Figure 13 shows the removal efficiency of CA/TPC for $\mathrm{Cr}^{3+}, \mathrm{Ni}^{2+}$ and $\mathrm{Zn}^{2+}$ over four successive adsorption/desorption cycles. In all the cases, the loss in the dry weight of CA/TPC was not more than $10 \%$ after each cycle. It was observed that about $\sim 94,92$ and $91 \%$ removal efficiencies of $\mathrm{Cr}^{3+}$, The highest desorption's for all of the metals achieved in first cycle of the elution at $\mathrm{pH} 1$. On 
Table 4 Equilibrium isotherm parameters for $\mathrm{Cr}^{3+}, \mathrm{Ni}^{2+}$ and $\mathrm{Zn}^{2+}$ adsorption (pH 3.0; AD $10.0 \mathrm{~g}$; agitation time $2 \mathrm{~h}$ )

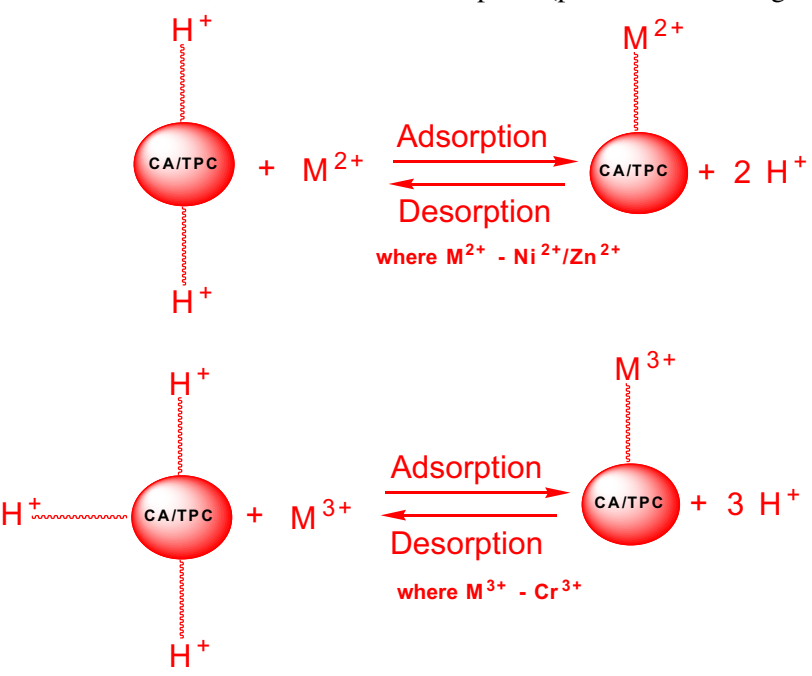

\begin{tabular}{|c|c|c|c|c|c|c|c|c|c|c|c|c|c|}
\hline \multirow[t]{2}{*}{ S. no. } & \multirow[t]{2}{*}{ Metal } & \multirow[t]{2}{*}{$T(\mathrm{~K})$} & \multicolumn{5}{|c|}{ Langmuir } & \multicolumn{3}{|c|}{ Freundlich } & \multicolumn{3}{|c|}{ Temkin } \\
\hline & & & $q_{\mathrm{m},(\exp )}$ & $q_{\mathrm{m},(\mathrm{Cal})}$ & $b$ & $\chi^{2}$ & $R^{2}$ & $n$ & $K_{\mathrm{f}}$ & $R^{2}$ & $a$ & $b$ & $R^{2}$ \\
\hline 1. & $\mathrm{Cr}^{3+}$ & 298 & 15.0 & 19.6 & 0.7 & 1.0 & 0.99 & 2.9 & 0.05 & 0.88 & 1.0 & $8.1 \times 10^{2}$ & 0.95 \\
\hline 2. & & 308 & 24.5 & 32.2 & 1.0 & 1.8 & 0.99 & 2.5 & 0.04 & 0.91 & 1.0 & $4.8 \times 10^{2}$ & 0.95 \\
\hline 3. & & 313 & 31.5 & 31.2 & 3.5 & 0.02 & 0.99 & 3.5 & 0.11 & 0.98 & 1.6 & $5.7 \times 10^{2}$ & 0.98 \\
\hline 4. & $\mathrm{Ni}^{2+}$ & 298 & 19.7 & 23.2 & 1.05 & 0.5 & 0.99 & 1.90 & 2.2 & 0.89 & 0.3 & $4.5 \times 10^{2}$ & 0.97 \\
\hline 5. & & 308 & 30.0 & 31.2 & 0.27 & 0.1 & 0.99 & 1.94 & 3.1 & 0.91 & 0.7 & $3.0 \times 10^{2}$ & 0.97 \\
\hline 6. & & 313 & 43.7 & 45.4 & 1.15 & 0.2 & 0.99 & 1.98 & 3.6 & 0.95 & 0.9 & $2.6 \times 10^{2}$ & 0.98 \\
\hline 7. & $\mathrm{Zn}^{2+}$ & 298 & 18.1 & 17.2 & 1.5 & 0.04 & 0.99 & 1.9 & 4.4 & 0.91 & 1.1 & $2.1 \times 10^{2}$ & 0.97 \\
\hline 8. & & 308 & 30.6 & 34.5 & 1.2 & 0.4 & 0.99 & 2.5 & 3.2 & 0.84 & 1.0 & $3.7 \times 10^{2}$ & 0.95 \\
\hline 9. & & 313 & 43.4 & 55.5 & 2.1 & 2.2 & 0.99 & 3.1 & 2.5 & 0.87 & 1.0 & $7.0 \times 10^{2}$ & 0.98 \\
\hline
\end{tabular}

Table 5 Reported adsorption capacities $(\mathrm{mg} / \mathrm{g})$ for $\mathrm{Cr}^{3+}, \mathrm{Ni}^{2+}$ and $\mathrm{Zn}^{2+}$ by various adsorbents

${ }^{a}$ This work

b Sphagnum moss peat

\begin{tabular}{|c|c|c|c|c|c|c|c|}
\hline S. no. & Adsorbent & Metal & $q(\mathrm{mg} / \mathrm{g})$ & $\mathrm{pH}$ & System & Wastewater & References \\
\hline 1. & CA/TPC & $\mathrm{Zn}^{2+}$ & 43.4 & 4 & Batch & Synthetic & {$[\mathrm{TW}]^{\mathrm{a}}$} \\
\hline 2. & Natural zeolite & $\mathrm{Zn}^{2+}$ & 13.4 & - & Batch & Synthetic & {$[50]$} \\
\hline 3. & Fly ash & $\mathrm{Zn}^{2+}$ & 03.4 & 5 & Batch & Synthetic & {$[51]$} \\
\hline 4. & CA/TPC & $\mathrm{Ni}^{2+}$ & 43.7 & 4 & Batch & Synthetic & {$[\mathrm{TW}]^{\mathrm{a}}$} \\
\hline 5. & Tea factory waste & $\mathrm{Ni}^{2+}$ & 15.2 & 4 & Batch & Synthetic & {$[52]$} \\
\hline 6. & $\mathrm{SMP}^{\mathrm{b}}$ & $\mathrm{Ni}^{2+}$ & 9.10 & 7 & Batch & Synthetic & {$[54]$} \\
\hline 7. & Fly ash & $\mathrm{Ni}^{2+}$ & 3.90 & 5 & Batch & Synthetic & {$[51]$} \\
\hline 8. & CA/TPC & $\mathrm{Cr}^{3+}$ & 31.5 & 2 & Batch & Synthetic & {$[\mathrm{TW}]^{\mathrm{a}}$} \\
\hline 9. & $\mathrm{SMP}^{\mathrm{b}}$ & $\mathrm{Cr}^{3+}$ & 18.6 & 4 & Batch & Synthetic & {$[53]$} \\
\hline 10. & Cork powder & $\mathrm{Cr}^{3+}$ & 6.3 & 4 & Batch & Synthetic & {$[55]$} \\
\hline
\end{tabular}

$\mathrm{Ni}^{2+}$ and $\mathrm{Zn}^{2+}$ were reached in the first cycle and over $\sim 87,84$ and $83 \%$ efficiencies were obtained in the fourth adsorption/desorption cycle, demonstrating that the prepared material is cost-effective, and regeneration of it by $0.1 \mathrm{~N} \mathrm{HNO}_{3}$ solution is quite easy. The metals containing regeneration solution after desorption were precipitate out as complex hydroxide from the solution on addition of $\mathrm{NH}_{4} \mathrm{OH}, \quad \mathrm{NaOH}$ and $\mathrm{Ca}(\mathrm{OH})_{2}$ into the 
Table 6 Kinetic models for $\mathrm{Cr}^{3+}, \mathrm{Ni}^{2+}$ and $\mathrm{Zn}^{2+}$ adsorption (pH 3.0; AD $10.0 \mathrm{~g}$; agitation time $2 \mathrm{~h}$ )

\begin{tabular}{|c|c|c|c|c|c|c|c|c|c|c|c|c|c|}
\hline \multirow[t]{2}{*}{ S. no. } & \multirow[t]{2}{*}{ Metal } & \multirow[t]{2}{*}{$T(\mathrm{~K})$} & \multicolumn{3}{|c|}{ Pseudo-second order } & \multicolumn{8}{|c|}{ Weber and Morris intraparticle diffusion } \\
\hline & & & $K_{2}$ & $q_{\mathrm{e}, \text { (cal.) }}$ & $h$ & $R^{2}$ & $k_{\text {id } 1}$ & $C$ & $R^{2}$ & $k_{\text {id } 2}$ & $C$ & $R^{2}$ & $q_{\mathrm{e},(\exp )}$ \\
\hline 1. & $\mathrm{Cr}^{3+}$ & 298 & 0.007 & 41.6 & 11.9 & 0.999 & 3.71 & 13.6 & 0.982 & 0.045 & 39.46 & 0.293 & 40.0 \\
\hline 2. & & 308 & 0.008 & 62.5 & 33.3 & 0.999 & 3.77 & 33.5 & 0.383 & 0.042 & 59.41 & 0.291 & 60.0 \\
\hline 3. & & 313 & 0.010 & 66.6 & 45.4 & 1.000 & 3.52 & 39.8 & 0.997 & 0.022 & 64.23 & 0.295 & 64.5 \\
\hline 4. & $\mathrm{Ni}^{2+}$ & 298 & 0.010 & 55.5 & 31.2 & 1.000 & 1.53 & 39.8 & 0.989 & 0.013 & 52.55 & 0.293 & 52.2 \\
\hline 5. & & 308 & 0.014 & 66.6 & 62.5 & 1.000 & 1.95 & 46 & 0.999 & 0.011 & 62.2 & 0.280 & 62.0 \\
\hline 6. & & 313 & 0.012 & 76.8 & 77.2 & 1.000 & 2.27 & 62.6 & 0.999 & 0.010 & 80.9 & 0.280 & 80.5 \\
\hline 7. & $\mathrm{Zn}^{2+}$ & 298 & 0.007 & 52.6 & 20 & 0.999 & 3.71 & 23.60 & 0.982 & 0.039 & 49.33 & 0.305 & 50.0 \\
\hline 8. & & 308 & 0.009 & 66.6 & 38.4 & 0.999 & 3.77 & 38.53 & 0.989 & 0.019 & 64.66 & 0.306 & 65.0 \\
\hline 9. & & 313 & 0.010 & 76.9 & 62.5 & 1.000 & 3.43 & 50.23 & 0.994 & 0.019 & 74.16 & 0.306 & 74.5 \\
\hline
\end{tabular}

Table 7 Thermodynamic parameters for $\mathrm{Cr}^{3+}, \mathrm{Ni}^{2+}$ and $\mathrm{Zn}^{2+}$ adsorption (T 298-318 K; pH 3.0 and 6.0; AD $10.0 \mathrm{~g}$; agitation time 2 h)

\begin{tabular}{|c|c|c|c|c|c|c|c|c|c|c|}
\hline \multirow[t]{2}{*}{ S. no. } & \multirow[t]{2}{*}{ Metal } & \multirow[t]{2}{*}{ Concentration $\left(\mathrm{mg} / \mathrm{dm}^{3}\right)$} & \multirow[t]{2}{*}{$\left(R^{2}\right)$} & \multirow[t]{2}{*}{$(\Delta S)$} & \multirow[t]{2}{*}{$(\Delta H)$} & \multicolumn{5}{|l|}{$(\Delta G)$} \\
\hline & & & & & & $298 \mathrm{~K}$ & $303 \mathrm{~K}$ & $308 \mathrm{~K}$ & $313 \mathrm{~K}$ & $318 \mathrm{~K}$ \\
\hline 1. & $\mathrm{Cr}^{3+}$ & 02 & 0.954 & 31.48 & 09.30 & -09371.7 & -09529.4 & -09686.5 & -09843.9 & $-10,001.3$ \\
\hline 2. & & 05 & 0.973 & 26.59 & 08.02 & -07918.8 & -08051.8 & -08184.8 & -08286.5 & $-8,419.40$ \\
\hline 3. & & 10 & 0.943 & 21.70 & 06.81 & -06459.8 & -06568.3 & -06676.8 & -06785.3 & $-6,893.14$ \\
\hline 4. & & 12 & 0.948 & 21.68 & 06.90 & -06429.9 & -06537.9 & -06645.9 & -06753.9 & $-6,861.90$ \\
\hline 5. & & 15 & 0.987 & 27.00 & 08.63 & -08037.4 & -08172.4 & -08307.4 & -08442.4 & $-8,577.41$ \\
\hline 6. & $\mathrm{Ni}^{2+}$ & 02 & 0.964 & 52.95 & 16.94 & $-15,762.1$ & $-16,042.0$ & $-16,307.3$ & $-16,572.4$ & $-16,837.1$ \\
\hline 7. & & 05 & 0.938 & 48.22 & 15.25 & $-14,289.2$ & $-14,529.1$ & $-14,769.2$ & $-15,009.1$ & $-16,249.4$ \\
\hline 8. & & 10 & 0.950 & 35.97 & 11.27 & $-10,717.1$ & $-10,896.7$ & $-11,076.7$ & $-11,256.7$ & $-11,436.7$ \\
\hline 9. & & 12 & 0.942 & 34.57 & 10.58 & $-10,270.5$ & $-10,442.7$ & $-10,615.4$ & $-10,782.9$ & $-10,960.4$ \\
\hline 10. & & 15 & 0.903 & 49.84 & 15.07 & $-14,825.4$ & $-15,074.4$ & $-15,323.4$ & $-15,572.4$ & $-15,834.0$ \\
\hline 11. & $\mathrm{Zn}^{2+}$ & 02 & 0.945 & 25.19 & 08.05 & -07498.6 & -07624.5 & -07750.5 & -07876.4 & -08002.4 \\
\hline 12. & & 05 & 0.876 & 35.06 & 10.10 & $-10,419.9$ & $-10,594.9$ & $-10,769.9$ & $-10,944.9$ & $-11,119.9$ \\
\hline 13. & & 10 & 0.862 & 33.51 & 10.50 & $-9,972.51$ & $-10,140.1$ & $-10,307.5$ & $-10,475.1$ & $-10,642.5$ \\
\hline 14. & & 12 & 0.935 & 43.42 & 13.20 & $-12,920.1$ & $-13,143.3$ & $-13,354.2$ & $-13,571.4$ & $-13,788.4$ \\
\hline 15. & & 15 & 0.969 & 41.47 & 12.30 & $-12,324.9$ & $-12,531.9$ & $-12,738.9$ & $-12,945.9$ & $-13,152.9$ \\
\hline
\end{tabular}

solution. The $\mathrm{Cr}^{3+}, \mathrm{Ni}^{2+}$ and $\mathrm{Zn}^{2+}$ ions were almost insoluble at $\mathrm{pH} \geq 7.5,9.5$ and $\geq 9.0$ that forms precipitate of $\mathrm{Cr}(\mathrm{OH})_{3}, \quad \mathrm{Ni}(\mathrm{OH})_{2}$ and $\mathrm{Zn}(\mathrm{OH})_{2}$ in solution. The chromium, nickel and zinc metals present in the precipitated solid volume were then effectively recovered. The adsorption and desorption process on CA/TPC is shown by the following mechanism:

$$
\begin{aligned}
& \mathrm{Cr}^{3+}(\mathrm{aq})+2 \mathrm{NH}_{4} \mathrm{OH}(\mathrm{aq}) \stackrel{\mathrm{pH} \geq 7.5}{\mathrm{Cr}(\mathrm{OH})_{3} \downarrow+2 \mathrm{NH}_{4}^{+}} \\
& \mathrm{Ni}^{2+}(\mathrm{aq})+2 \mathrm{NaOH}(\mathrm{aq}) \stackrel{\mathrm{pH} \geq 9.5}{\longrightarrow} \mathrm{Ni}(\mathrm{OH})_{2} \downarrow+2 \mathrm{Na}^{+} \\
& (\mathrm{Greenprecipitates}) \\
& \mathrm{Zn}^{2+}(\mathrm{aq})+2 \mathrm{Ca}(\mathrm{OH})_{2}(\mathrm{aq}) \stackrel{\mathrm{pH} \geq 9}{\longrightarrow} \underset{\mathrm{Zn}(\mathrm{OH})_{2} \downarrow+2 \mathrm{Ca}^{2+}}{(\text { White precipitates })}
\end{aligned}
$$

\section{Competitive adsorption}

The competitive adsorption among the chromium, nickel and zinc metal ions was studied, Fig. 14. In the presence of three metals with equal concentrations, the observed adsorption efficiencies of CA/TPC for $\mathrm{Cr}^{3+}, \mathrm{Ni}^{2+}$ and $\mathrm{Zn}^{2+}$ were $32.1,96.1$ and $33.6 \%$, respectively. For $\mathrm{Ni}^{2+}$ and $\mathrm{Zn}^{2+}$ metal binary solution, the efficiency for $\mathrm{Ni}^{2+}$ was $36 \%$ more than its competitive $\mathrm{Zn}^{2+}$ ion while in $\mathrm{Ni}^{2+}$ and $\mathrm{Cr}^{3+}$ mixed solution, the removal for $\mathrm{Ni}^{2+}$ was almost double of $\mathrm{Cr}^{3+}$ ion. These outcomes revealed that in the presence of $\mathrm{Ni}^{2+}$, adsorptions of $\mathrm{Zn}^{2+}$ and $\mathrm{Cr}^{3+}$ were strongly affected. The observed change in adsorption behaviors may be due to the nature of metal ions and the interaction between CA/TPC and adsorbate species [49]. 


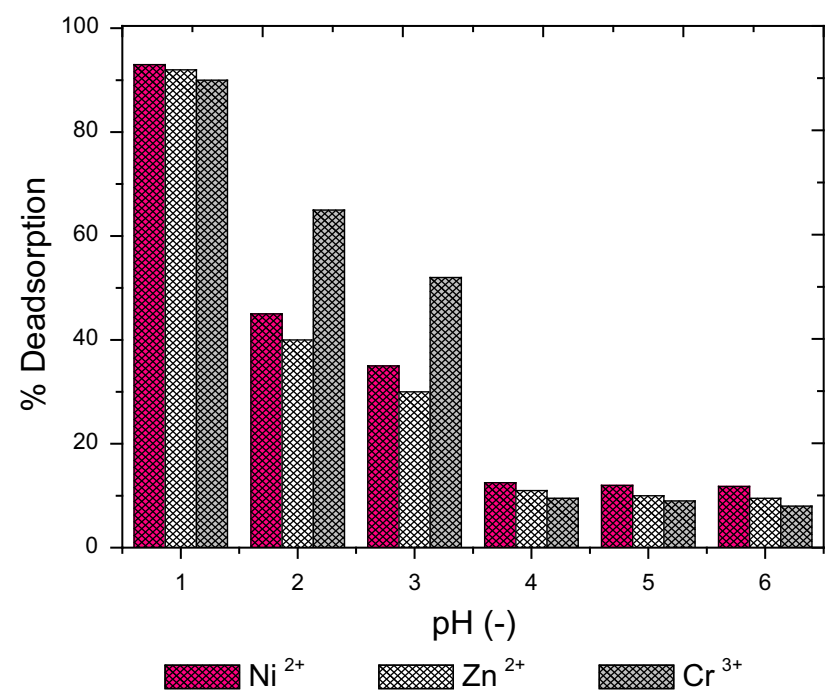

Fig. 12 Percent desorption against various $\mathrm{pH} \mathrm{s}$ of solution ( $\mathrm{T}$ $298 \mathrm{~K}$; CA/TPC dosage $1.0 \mathrm{~g}$; time $8 \mathrm{~h}$ )

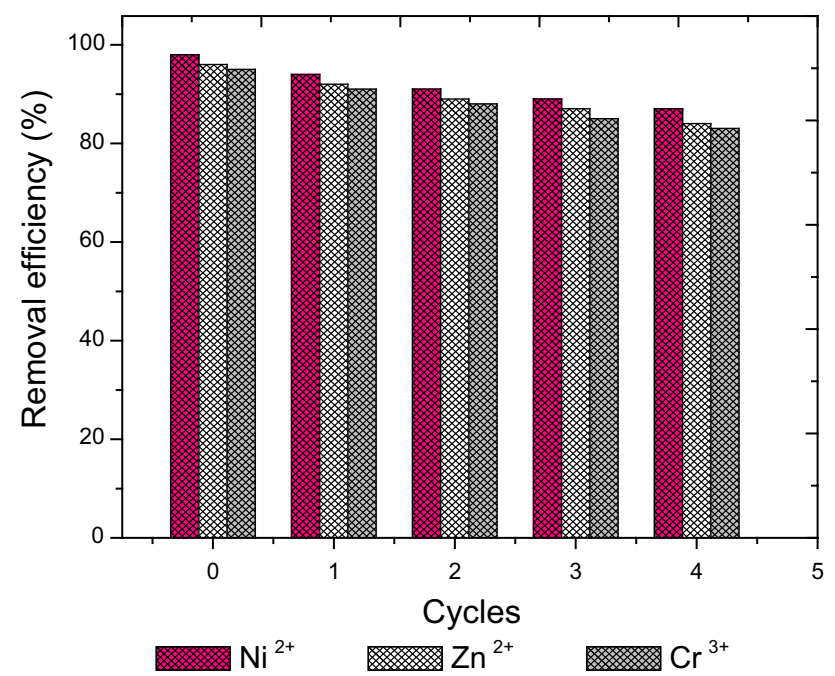

Fig. 13 Four consecutive adsorption/desorption cycles of CA/TPC for $\mathrm{Cr}^{3+}, \mathrm{Ni}^{2+}$ and $\mathrm{Zn}^{2+}$ (conc. $15 \mathrm{mg} / \mathrm{dm}^{3}$; CA/TPC dosage $1.0 \mathrm{~g}$; T $313 \mathrm{~K}$; pH 3 and 5; desorption agent; and $20 \mathrm{~cm}^{3}$ of $0.1 \mathrm{~N} \mathrm{HNO}_{3}$ )

Application to electroplating wastewater

The applicability of the present material for electroplating wastewater system was tested. For the purpose, waste water samples were collected from electroplating units of Jalandhar city of Punjab (India). The concentrations of metals in the effluent sample were analyzed, Table 2 . As shown in Table 1, the fresh samples of chromium, nickel and zinc water $\left(100 \mathrm{~cm}^{3}\right.$ each) were collected from electroplating units and mixed in equal volume proportion by volume $(1: 1: 1 \mathrm{v} / \mathrm{v})$. The resultant mixed sample solution was treated with fixed concentration of nitric acid followed by

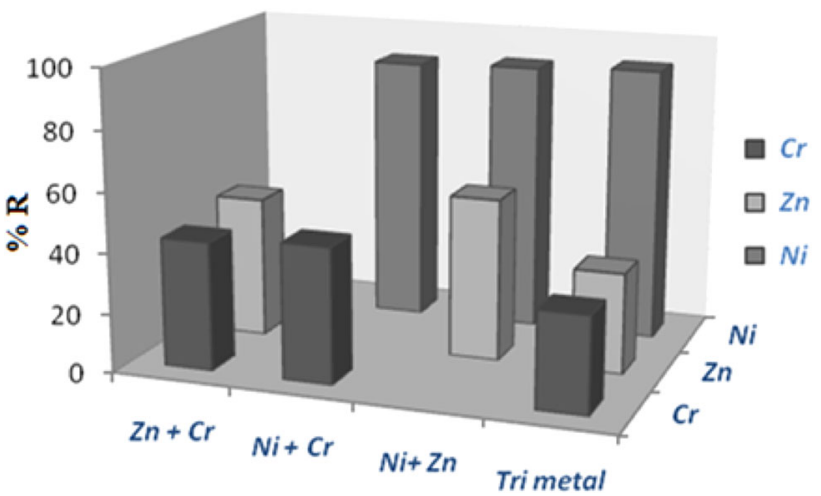

Fig. 14 Competitive adsorption of multimetal solution (CA/TPC dose $10.0 \mathrm{~g}$; $\mathrm{pH} 3$ and 6 ; agitation time $2 \mathrm{~h}$; metal concentration $15 \mathrm{mg} / \mathrm{dm}^{3}$ )

$\mathrm{pH}$ adjustment between 3.0 and 6.0 using buffer solution. Batch experiment was carried out by adding $50 \mathrm{~cm}^{3}$ of mixed sample in a conical flask taking $1.0 \mathrm{~g}$ of CA/TPC under optimized conditions as described. Percent removal efficiencies of CA/TPC for chromium, nickel and zinc were found to be $87.2,94.4$ and 90.5 , respectively. It has been estimated that $1 \mathrm{~m}^{3}$ of effluent discharge containing average $16.21,15.41$ and $13.23 \mathrm{mg} / \mathrm{dm}^{3}$ chromium, nickel and zinc metals required $\sim 1.5 \mathrm{~kg}$ of adsorbent to meet the discharge limit imposed by law.

\section{Conclusion}

The results from the present study exhibit the application potential of CA/TPC for the effective removal and recovery of chromium, nickel and zinc from simple and electroplating wastewater. The optimum $\mathrm{Ni}^{2+}$ and $\mathrm{Zn}^{2+}$ adsorption was found to occur in $\mathrm{pH}$ range of 4-6, whereas best $\mathrm{Cr}^{3+}$ adsorption was achieved at $\mathrm{pH} 3$. The adsorption isotherms for $\mathrm{Cr}^{3+}, \mathrm{Ni}^{2+}$ and $\mathrm{Zn}^{2+}$ uptake at given temperatures were best represented by the Langmuir model $\left(R^{2}>0.99\right)$ suggesting that the surface was relatively homogenous in terms of functional groups. The kinetics data for $\mathrm{Cr}^{3+}, \mathrm{Ni}^{2+}$ and $\mathrm{Zn}^{2+}$ adsorptions were best fitted in pseudo-second-order rate equation as evident from the regression coefficients $\left(R^{2}>0.99\right)$. Thermodynamic data illustrate that $\mathrm{Cr}^{3+}, \mathrm{Ni}^{2+}$ and $\mathrm{Zn}^{2+}$ adsorption reactions were endothermic and spontaneous. The adsorbed $\mathrm{Cr}^{3+}, \mathrm{Ni}^{2+}$ and $\mathrm{Zn}^{2+}$ ions were best recovered using $0.1 \mathrm{~N} \mathrm{HNO}_{3}$ solutions at system $\mathrm{pH} 1$, and the regenerated $\mathrm{CA} / \mathrm{TPC}$ was effectively used up for four consecutive cycles with $<10 \%$ loss in weight. The experimental data show that the CA/ TPC has reasonable good adsorption capacities for $\mathrm{Cr}^{3+}$, $\mathrm{Ni}^{2+}$ and $\mathrm{Zn}^{2+}$ ions. 
Acknowledgments One of the authors Suriti Sharma thanks the authorities of Dr. B. R. Ambedkar National Institute of Technology, Jalandhar, (Punjab) India, for providing all necessary laboratory facilities and infrastructure to carry out the present work.

Open Access This article is distributed under the terms of the Creative Commons Attribution License which permits any use, distribution, and reproduction in any medium, provided the original author(s) and the source are credited.

\section{References}

1. Gupta VK, Jain R, Nayak A, Agarwal S, Shrivastava M (2011) Removal of the hazardous dye: tartrazine by photodegradation on titanium dioxide surface. Mater Sci Eng C 31:1062-1067

2. Khani H, Rofouei MK, Arab P, Gupta VK, Vafaei Z (2010) Multi-walled carbon nanotubes-ionic liquid carbon paste electrode as a super selectivity sensor: application to potentiometric monitoring of mercury ion (II). J Hazard Mater 183:402-409

3. Owlad M, Aroua MK, Daud WAW, Baroutian S (2008) Removal of hexavelant chromium contaminated water and wastewater: a review. Water Air Soil Pollut 200:59-77

4. Gupta VK, Ali I, Saleh TA, Nayak A, Agarwal S (2012) Chemical treatment technologies for waste-water recycling: an overview. RSC Adv 2:6380-6388

5. Saleh TA, Gupta VK (2012) Column with CNT/magnesium oxide composite for lead (II) removal from water. Environ Sci Pollut Res 19:1224-1228

6. Gupta VK, Srivastava SK, Mohan D, Sharma S (1998) Design parameters for fixed bed reactors of activated carbon developed from fertilizer waste for the removal of some heavy metal ions. Waste Manag 17:517-522

7. Mittal A, Mittal J, Malviya A, Kaur D, Gupta VK (2010) Decoloration treatment of a hazardous triarylmethane dye, Light Green SF (Yellowish) by waste material adsorbents. J Colloid Interf Sci 342:518-527

8. Mittal A, Kaur D, Malviya A, Mittal J, Gupta VK (2009) Adsorption studies on the removal of coloring agent phenol red from wastewater using waste materials as adsorbents. J Colloid Interf Sci 337:345-354

9. Mittal A, Mittal J, Malviya A, Gupta VK (2009) Adsorptive removal of hazardous anionic dye "Congo red" from wastewater using waste materials and recovery by desorption. J Colloid Interf Sci 340:16-26

10. Mittal A, Mittal J, Malviya A, Gupta VK (2010) Removal and recovery of Chrysoidine $\mathrm{Y}$ from aqueous solutions by waste materials. J Colloid Interf Sci 344:497-507

11. Saleh TA, Gupta VK (2012) Photo-catalyzed degradation of hazardous dye methyl orange by use of a composite catalyst consisting of multi-walled carbon nanotubes and titanium dioxide. J Colloid Interf Sci 371:101-106

12. Gupta VK, Agarwal S, Saleh TA (2011) Synthesis and characterization of alumina-coated carbon nanotubes and their application for lead removal. J Hazard Mater 185:17-23

13. Gupta VK, Nayak A (2012) Cadmium removal and recovery from aqueous solutions by novel adsorbents prepared from orange peel and $\mathrm{Fe}_{2} \mathrm{O}_{3}$ nanoparticles. Chem Eng J 180:81-90

14. Jain AK, Gupta VK, Bhatnagar A, Suhas (2003) A comparative study of adsorbents prepared from industrial wastes for removal of dyes. Sep Sci Technol 38:463-481

15. Sharma S, Kothiyal NC (2013) Use of activated dry flowers (ADF) of Alstonia scholaris for chromium (Vl) removal: equilibrium, kinetics, and thermodynamics studies. Environ Sci Pollut Res 20:8986-8995

16. Sharma S, Kothiyal NC (2013) Study of chromium (Vl) adsorption using Pterospermum-acerifolium fruit capsule activated carbon $(F C A C)$ and commercial activated charcoal (CAC) as a selective adsorbents. Holist Approach Environ 3:63-82

17. Case OP (1974) Metallic recovery from wastewaters utilizing cementation. EPA-270/2-74-008, US, Washington, DC

18. Gupta VK, Jain R, Mittal A, Saleh TA, Nayak A, Agarwal S, Sikarwar S (2012) Photo-catalytic degradation of toxic dye amaranth on $\mathrm{TiO}_{2} / \mathrm{UV}$ in aqueous suspensions. Mater Sci Eng C 32:12-17

19. Alyüz B, Veli S (2009) Kinetics and equilibrium studies for the removal of nickel and zinc from aqueous solutions by ion exchange resins. J Hazard Mater 167:482-488

20. Clearfield A (1982) Inorganic ion exchange materials. FloridaCRC Press, Boca Raton

21. Khan AM, Ganai SA, Nabi SA (2009) Synthesis of a crystalline organic-inorganic composite exchanger, acrylamide stannic silicomolybdate: binary and quantitative separation of metal ions. Colloids Surf A Physicochem Eng Asp 337:141-145

22. AL-Othman ZA, Naushad M, Nilchi A (2011) Development, characterization and ion exchange thermodynamics for a new crystalline composite cation exchange material: application for the removal of $\mathrm{Pb}^{2+}$ ion from a standard sample (Rompin Hematite). J Inorg Organomet Polym 21:547-559

23. Khan A, Asiri AM, Rub MA, Azum N, Khan AAP, Khan I, Mondal PK (2012) Review on composite cation exchanger as interdicipilinary materials in analytical chemistry. Int $\mathrm{J}$ Electrochem Sci 7:3854-3902

24. Naushad M, AL-Othman ZA, Islam M (2013) Adsorption of cadmium ion using a new composite cationexchanger polyaniline Sn(IV) silicate: kinetics, thermodynamic and isotherm studies. Int J Environ Sci Technol 10:567-578

25. Varshney KG, Rafiquee MZA, Somya A, Drabik M (2006) Synthesis and characterization of $\mathrm{Hg}$ (1l) selective $n$-butyl acetate cerium (IV) phosphate as a new intercalated fibrous ion exchanger: effect of surfactants on the adsorption behavior. Ind J Chem 45A:1856-1860

26. El-Naggar IM, Zakaria ES, Ali IM, Khalil M, El-Shahat MF (2012) Kinetic modeling analysis for the removal of cesium ions from aqueous solutions using polyaniline titanotungstate. Arab J Chem 5:109-119

27. Khan AA, Khan A, Habiba U, Paquiza L, Ali S (2011) Preparation and characterization of electrically conducting polypyrrole Sn (IV) phosphate cation-exchanger and its application as Mn(II) ion selective membrane electrode. J Adv Res 2:341-349

28. Khan AA, Habiba U, Khan A (2009) Synthesis and characterization of organic-inorganic nanocomposite poly-o-anisidine $\mathrm{Sn}(\mathrm{IV})$ arsenophosphate: its analytical applications as $\mathrm{Pb}(\mathrm{II})$ ionselective membrane electrode. Int J Anal Chem. doi:10.1155/ 2009/659215

29. Mispa KJ, Subramaniam P, Murugesan R (2013) Studies on ionexchange properties of polyaniline $\mathrm{Zr}$ (IV) tungstoiodophosphate nanocomposite ion exchanger. J Polym. doi:10.1155/2013/ 356058

30. Gupta VK, Agarwal S, Pathania D, Kothiyal NC, Sharma G (2013) Use of pectin-thorium (IV) tungstomolybdate nanocomposite for photocatalytic degradation of methylene blue. Carbohydr Polym 96:277-283

31. Gupta VK, Pathania D, Singh P, Rathore BS, Chauhan P (2013) Cellulose acetate-zirconium (IV) phosphate nanocomposite with enhanced photo-catalytic activity. Carbohydr Polym 95:434-440

32. Rathore BS, Sharma G, Pathania D, Gupta VK (2014) Synthesis, characterization and antibacterial activity of celluloseacetate-tin (IV) phosphate nanocomposite. Carbohydr Polym 103:221-227 
33. Khan A, Khan AAP, Asiri AM, Rub MA (2014) Synthesis of silver embedded poly (o-anisidine) molybdophosphate nano hybrid cation-exchanger applicable for membrane electrode. PLoS One. doi:10.1371/journal.pone.0096897

34. Khan MR (2014) Transport phenomena of inorganic-organic cation exchange nanocomposite membrane: a comparative study with different methods. J Nanostruct Chem. doi:10.1007/s40097014-0095-0

35. Nabi SA, Naushad Mu (2008) Synthesis, characterisation and analytical application of a new composite cation exchanger cellulose acetate-Zr (IV) molybdophosphate. Colloids Surf A 316:217-225

36. Nabi SA, Naushad Mu, Bushra R (2009) Synthesis and characterization of a new organic-inorganic $\mathrm{Pb}^{2+}$ selective composite cation exchanger acrylonitrile stannic (IV) tungstate and its analytical applications. Chem Eng J 152:80-87

37. Nabi SA, Naushad Mu, Bushra R (2009) A new hybrid EDTAzirconium phosphate cation exchanger: synthesis, characterization and adsorption behaviour for environmental monitoring. Adsorpt Sci Technol 27:423-437

38. Siddiqui WA, Khan SA, Inamuddin SA (2007) Synthesis, characterization and ion exchange properties of a new and novel organic-inorganic hybrid cation exchanger: poly (methyl methacrylate) Zr(IV) phosphate. Colloids Surf A 295:193-199

39. Sanchez C, Julian B, Belleville P, Popall M (2005) Applications of hybrid organic-inorganic nanocomposites. J Mater Chem 15:3559-3592

40. Naushad M (2014) Surfactant assisted nano-composite cation exchanger: development, characterization and applications for the removal of toxic $\mathrm{Pb}^{2+}$ from aqueous medium. Chem Eng $\mathrm{J}$ 235:100-108

41. Freundlich H (1906) Uber die adsorption in losungen. Zeitschrift fur Physikalische Chemie 57:385-470

42. Sharma S, Kothiyal NC (2012) Removal of Cr(VI) from aqueous solution by polymer based guar gum-g-poly (AAm) and activated charcoal adsorbents. Holistic Approach Environ 2:3-22

43. Pandey PK, Sharma SK, Sambi SS (2010) Kinetics and equilibrium study of chromium adsorption on zeoliteNaX. Int J Environ Sci Technol 7:395-404
44. Ho Y (2006) Review of second-order models for adsorption systems. J Hazard Mater B136:681-689

45. Sahu SK, Meshrama P, Pandey BD, Kumar V, Mankhand TR (2009) Removal of chromium (III) by cation exchange resin, Indion 790 for tannery waste treatment. Hydrometallurgy 99:170-174

46. Kumar E, Bhatnagar A, Choi JA, Kumar U, Min B, Kim Y, Songd H, Paeng KJ, Jung YM, Abou-Shanab RAI, Jeon BH (2010) Perchlorate removal from aqueous solutions by granular ferric hydroxide (GFH). Chem Eng J 159:84-90

47. Karthikeyan S, Gupta VK, Boopathy R, Titus A, Sekaran G (2012) A new approach for the degradation of high concentration of aromatic amine by heterocatalytic Fenton oxidation: kinetic and spectroscopic studies. J Mol Liquids 173:153-163

48. Green wood NN, Earnshaw A (2011) Chemistry of the elements (2/e). Elsevier, Butterworth-Heinemann

49. Pang Y, Zeng G, Tang L, Zhang Y, Liu Y, Lei X, Li Z, Zhang J, Xie G (2011) PEI-grafted magnetic porous powder for highly effective adsorption of heavy metal ions. Desalination 281:278-284

50. Erdem E, Karapinar N, Donat R (2004) The removal of heavy metal cations by natural zeolites. J Colloid Interf Sci 261:309-314

51. Ricou P, Lecuyer L, Le Cloiree P (1998) Influence of operating conditions on heavy metal cation removal by fly ash in aqueous solutions. Environ Technol 19:1005-1016

52. Malkoc E, Nuhoglu Y (2005) Investigations of nickel (II) removal from aqueous solutions using tea factory waste. J Hazard Mater 127:120-128

53. Balan C, Bilba D, Macoveanu M (2009) Studies on chromium (III) removal from aqueous solutions by sorption on Sphagnum moss peat. J Serb Chem Soc 74:953-964

54. Ho YS, John Wase DA, Forster CF (1995) Batch nickel removal from aqueous solution by sphagnum moss peat. War Res 29:1327-1332

55. Machado R, Carvalho JR, Correia MJN (2002) Removal of trivalent chromium (III) from solution by biosorption in cork powder. J Chem Technol Biotechnol 77:1340-1348

56. Levine RI, Rubin DS (2005) Statistics for management (7/e). Prentice-Hall, Pearson Education 